\title{
Exploring the Fringe-Belt Phenomenon in a Multi- Nuclear City: The Case of Istanbul
}

\section{Ayşe Sema Kubat}

\begin{abstract}
This paper examines historic land use changes to the fringe-belt zones of Istanbul, and in particular looks at the transformation of areas such as these into CBDs due to the effects of urban growth development cycles. The study is based on detailed research into the selected case study areas regarding changes in their land-uses within the overall urban development pattern of Istanbul. Once in the periphery, many of these areas now reflect CBD characteristics as a result of their development cycles. Urban fringe-belts are the urban peripheries of earlier periods that have become enveloped by the city through urban growth, and over time these areas adjust to the ever changing dynamics of urban land-use. In contrast to the dense urban texture of previously developed regions of the city, fringe-belts have a more loose texture and frequently retain the potential for the creation of public spaces. These include the open green areas, institutional areas, and industrial heritage sites that have connections with urban identity, and which are therefore essential for urban memory. Fringe-belts are both heritage areas and ecological corridors that create buffer zones to protect the natural landscape from urban sprawl. However, due to the requirements of rapid population
\end{abstract}

Keywords: Fringe belt, urban growth, CBD, urban morphology, Istanbul

* Faculty of Architecture, Istanbul Technical University, Istanbul, Turkey. ORCID E-mail: kubat@itu.edu.tr 
growth, they are often seen as potential development areas and those that remain become alienated. Understanding the formation and modification dynamics of fringe-belts is important for both the appreciation and management of cities, and also for the determination of urban areas' future development.

\section{INTRODUCTION}

Since the first cities were founded 10,000 years ago, they have undergone many changes in form. Most often, these changes have stemmed mainly from a city's unique economical, political and social dynamics. A comparative analysis of the changes that occur through history, and an examination of their components, allows a better understanding of the dynamics of different urban forms. A historico-geographical approach, therefore, becomes an important means by which to follow the evolution of a given urban form and to chart its spatial traces of change. Concepts such as fringe-belts, burgage cycles, and morphological regions are the products of this approach.

When they are mapped and studied systematically, it is evident that urban fringe-belts constitute major elements of the internal structure of cities, even though this may not be immediately apparent to those on the ground, and is most noticeable in places where a fixation line exerts a powerful constraining influence. In addition, once fringe-belts have been established, it is common for them to have a marked effect on subsequent developments, and for this reason their study is a particularly valuable means of structuring a historico-geographical account of the developing forms of cities (Whitehand, 2007).

As the CBD reflects centralizing forces that concentrate businesses and control functions at the urban core (Murphy 1966), fringe-belts are those portions of the urban area defined by the accumulation of larger space-using sites and structures that were originally located further at the periphery (Whitehand, 1967). The CBD is distinguished by the density and tight texture of its built form; residential districts by their general compactness; and fringe-belts by their significantly looser, more open patterns of land coverage and the availability of larger plots (Conzen 2009).

This study aims to identify the fringe-belt formation and modification processes that continue to occur during the urban growth cycle of Istanbul by identifying the city's substratum as well as the permanent structures that have shaped it so far. Istanbul is located at a key strategic geographical location (at the meeting point of the two continents, Europe and Asia) and it has 
had a long and magnificent history due to its being the capital of the Roman, Byzantine and Ottoman Empires (Kubat, 1999).

Urban morphologists and geographers have been studying the concept of the urban fringe-belt since the 1960s. Although previous studies have demonstrated the validity of the fringe in a variety of regions around the world (Conzen 2009), they have usually focused on small cities (Whithorn and Bromsgrove in Britain) or large cities that developed from a single center such as the Tyneside conurbation, Birmingham, Baghdad, Lusaka, and Auckland (Conzen, 2009). However, there has been little examination of Fringe Belt concept with regard to the multicentered cities of the developing world. It is therefore timely to make an attempt to fill this void, particularly in the light of the challenges for urban planning facing the central areas of Istanbul, a multi-nuclear metropolitan city with a current population of around 15 million people.

Studies on the urban growth of Turkish cities from viewpoint of urban morphology are very limited but they have been increasing over last decade. Ünlü (2013) focuses on the formation and modification of the inner fringe belt of Mersin, which is furthered by Ünlü and Baş (2016) through an investigation of fringe belt development on a citywide scale. They examine the relationship between distinct fringe belts and provide an explanation of multinuclear urban growth with reference to fringe-belt development. Ünlü and Baş identified the development periods of Turkish cities to their fringe belts within the temporal framework, from $19^{\text {th }}$ century until the present day (Ünlü, Baş, 2019).

This study seeks to fill this gap by giving special attention to Istanbul, and by examining the impact of urban growth and CBD transformation on the formation and modification processes of its fringe-belt areas. However, more explicit operational methods and examples are needed to reveal the benefits of the fringe-belt concept to the policy makers and urban planners.

\section{FRINGE BELT CONCEPT}

Conzen defined a fringe-belt as "a belt-like zone originating from the temporarily stationary or very slowly advancing fringe of a town and composed of a characteristic mixture of land-use units initially seeking a peripheral location" (Conzen, 1960). During periods of urban growth, the areas that best reflect fringe-belt characteristics are those urban units that were initially located in the periphery. These were later enveloped by the city, but still remain different from more densely structured areas in terms of their textures and functions. 
Fringe-belts were first identified by Herbert Louis in a study of Berlin published in 1936. "Louis formulated the basic concept and made the first attempt to delineate fringe-belt zones cartographically. His accomplishment was to differentiate Berlin's entire metropolitan area into zones that were legible in terms of their historico-geographical development and to map those zones in detail" (Conzen, 2009; Louis, 1936). He demarcated areas according to how densely formed they were, labeling them as: heterogeneous built-up zones, industrial belts, allotment garden districts, villa quarters, and absorbed former village centers. The fringe-belt phenomenon and the associated processes of urban growth were further explored in the early 1960s by M.R.G. Conzen, a student of Louis, who examined Alnwick and Newcastleupon-Tyne (Conzen, 1960; 1962). Conzen also found three distinct belts in close association across what was, by comparison with Louis' Berlin case study, a very small built-up area (Whitehand, 1967).

After the studies of Conzen, the concept of the fringe-belt became a tool by which to explain urban growth (Whitehand, 1987). Building upon Conzen's studies, Jeremy Whitehand confirmed the utility of mapping fringe-belts in large urban settings such as the Tyneside conurbation and the cities of Glasgow and Birmingham. More importantly, however, he advanced the theoretical underpinnings of fringe-belt theory by using two major methods. First, he explored the relationship between fringe- belts and the pulses of urban building cycles, thereby proving statistically what Conzen had recognized intuitively. Second, he developed a mathematical model (the Building Cycle Model) that explains the generation of the belt area and site selection with respect to the economic cycles of the city/country (booms \& slumps) and changes in land price (Whitehand, 1967, 1972, 1987). By using factors such as distance from the center, accessibility to the periphery, and distance to services, Whitehand found that institutional uses favored these regions, and that the formation of these areas continued during times of economic recession despite falls in housing production; this is largely due to the concurrent drop in land prices. However, it has been mentioned that the formation of fringe- belt areas can also be a cause of declines in housing production for reasons other than those that originate within the building cycle and the rings of construction (Whitehand, 1988).

The use of fringe-belts may vary for reasons such as the choice to locate in the periphery, the need for relatively cheap, large spaces, and the attractiveness of their geographical features. These areas are characterized by the ownership of large units and a high 
proportion of open spaces (Whitehand and Morton, 2004). Green areas, urban agricultural areas, industrial areas, institutional areas, sports areas, low-density residential areas, and recreation areas are all commonly found within fringe-belts (Barke, 1982).

In his primary analyses, Conzen identified three fringe-belts: an inner fringe-belt (IFB), a middle fringe-belt (MFB) and an outer fringe-belt (OFB). Inner fringe-belts generally form around historic city centers, thereby becoming the oldest fringe-belt formation, and are often limited by fixation lines. Middle fringebelt areas are more distant from the center and are also associated with fixation lines. However, these can occur in areas closer to the centers of slow or under-growing cities. Compared to inner fringebelt areas, they are less continuous, their parcels are larger, they have more open areas and more vegetation, and major road networks are rare (M.P. Conzen, 2009). Outer fringe-belt areas are the most independent and generally consist of large, scattered, and rarely adjacent parcels. Although OFBs tend to have more open areas, these are less likely to be the product of fixation lines. Despite their differences, all fringe-belt areas are products of centrifugal forces, and as such they are affected by the dynamics of the central business district (CBD), which is the product of centripetal forces (Whitehand, 1967). Conzen (2009) drew attention to the fact that the pressure from CBD expansion and transformation have brought major changes to the IFBs of older cities, and studies of MFBs have shown them to be subject to pressure arising from the need for additional housing (Birmingham being the best explored case).

Table 1. Formation and Modification Phases of Fringe-Belts (reproduced from Conzen, 2009)

\begin{tabular}{|l|l|l|l|}
\hline \multicolumn{2}{|l|}{ Fringe-Belt Formation } & Fringe-Belt Modification \\
\hline $\begin{array}{l}\text { Fixation } \\
\text { Phase }\end{array}$ & $\begin{array}{l}\text { Incipient } \\
\text { character }\end{array}$ & FB Alienation & $\begin{array}{l}\text { Loss to } \\
\text { residential or } \\
\text { CBD }\end{array}$ \\
\hline $\begin{array}{l}\text { Expansion } \\
\text { Phase }\end{array}$ & $\begin{array}{l}\text { Pronounced } \\
\text { character }\end{array}$ & FB Reduction & Ditto \\
\hline $\begin{array}{l}\text { Consolidation } \\
\text { Phase }\end{array}$ & $\begin{array}{l}\text { Dominant } \\
\text { character }\end{array}$ & $\begin{array}{l}\text { FB } \\
\text { Translation }\end{array}$ & $\begin{array}{l}\text { Transfer to } \\
\text { another FB }\end{array}$ \\
\hline
\end{tabular}

Fringe-belt areas develop an internal history in parallel with the development dynamics of the city and pass through two grand stages, namely formation and modification (Table 1). In the formation stage, they progress from a fixation phase to an expansion phase, and then to a consolidation phase (Conzen, 
2009). Over time these once peripheral but now embedded fringebelts adjust to the ever- changing dynamics of urban growth and the CBD. After the formation stage, they can be perpetuated by attracting areas of similar character ( $F B$ accretion). However, if fringe-belt areas are located within a city, there will be greater pressure to change and they will be exposed to modification or expansion. Thus, fringe-belts may lose their size or coherence when radical or large scale redevelopment takes place (FB alienation and reduction) (Conzen, 2009). The different characterization of older fringe-belt areas (multi-storey office blocks and apartment buildings) and the allocation of parking spaces for redevelopment are some of the factors that cause the alienation of fringe-belts (Gu, 2010).

Michael Barke and Estelle Ducom have made two useful attempts to understand general fringe-belt dynamics. Barke (1990) schematized the permutations of land use change as fringe-belts multiply and mature. According to Barke (1990), the new land uses from these processes also affect the formation of new fringebelts. Ducom (2005), on the other hand, examined the interrelationship between decision takers, contributing factors, and the processes of modification as fringe-belts evolve. In this latter model, the formation of the fringe-belt is shaped as a result of the decision-making processes of the primary actors, namely those public administrators and private entrepreneurs who are influential in urban development. According to Ducom (2005), if urban expansion accelerates and/or there is stagnation in the use of these areas, they run the risk of losing their fringe-belt characteristics.

Although these processes apply to fringe-belts, they might also be expected to occur in all urban areas. However, there are also significant regional differences that stem from differing historical, socioeconomic and cultural development to be considered. With regard to this point, studies investigating such differences are important.

\section{METHODOLOGY}

Comparative map analysis is the main research methodology to be used when there is a focus on historical maps, aerial photos and development plans. Accordingly, in order to define the fringebelts of Istanbul, a comparative map analysis was conducted. The fringe-belt modification process of Istanbul was investigated by overlapping the city maps and development plans from different periods, and this was carried out in accordance with the work of Conzen and Whitehand. (Conzen, 2009, Whitehand, 2007). The current study is based on a method of data collection and analysis 
that concentrates on several land-use patterns linked to fringebelt land utilization (according to Conzen). The study selects among several land-use patterns that reflect the fringe belt land utilization characteristics; cemeteries, military areas, college grounds, hospitals, industrial areas, market gardens, sports and recreation areas, vast squares, parks and gardens, train stations, and low density residential areas.

For the analysis of the fringe-belt areas of Istanbul, each priority area was determined according to the city's main growth axes. From the European side, the Historical Peninsula, the Golden Horn, and the regions of Maslak and Ayazağa were selected as case study areas; and from the Anatolian (Asian) side, the Kadıköy region was selected. As part of this ongoing research project, the Taksim-Pera region on the European side - the key area on the linearly developing CBD axis - and the Üsküdar region from the Anatolian side of the city will be added as additional cases for analysis for the future studies (see Figure 1).

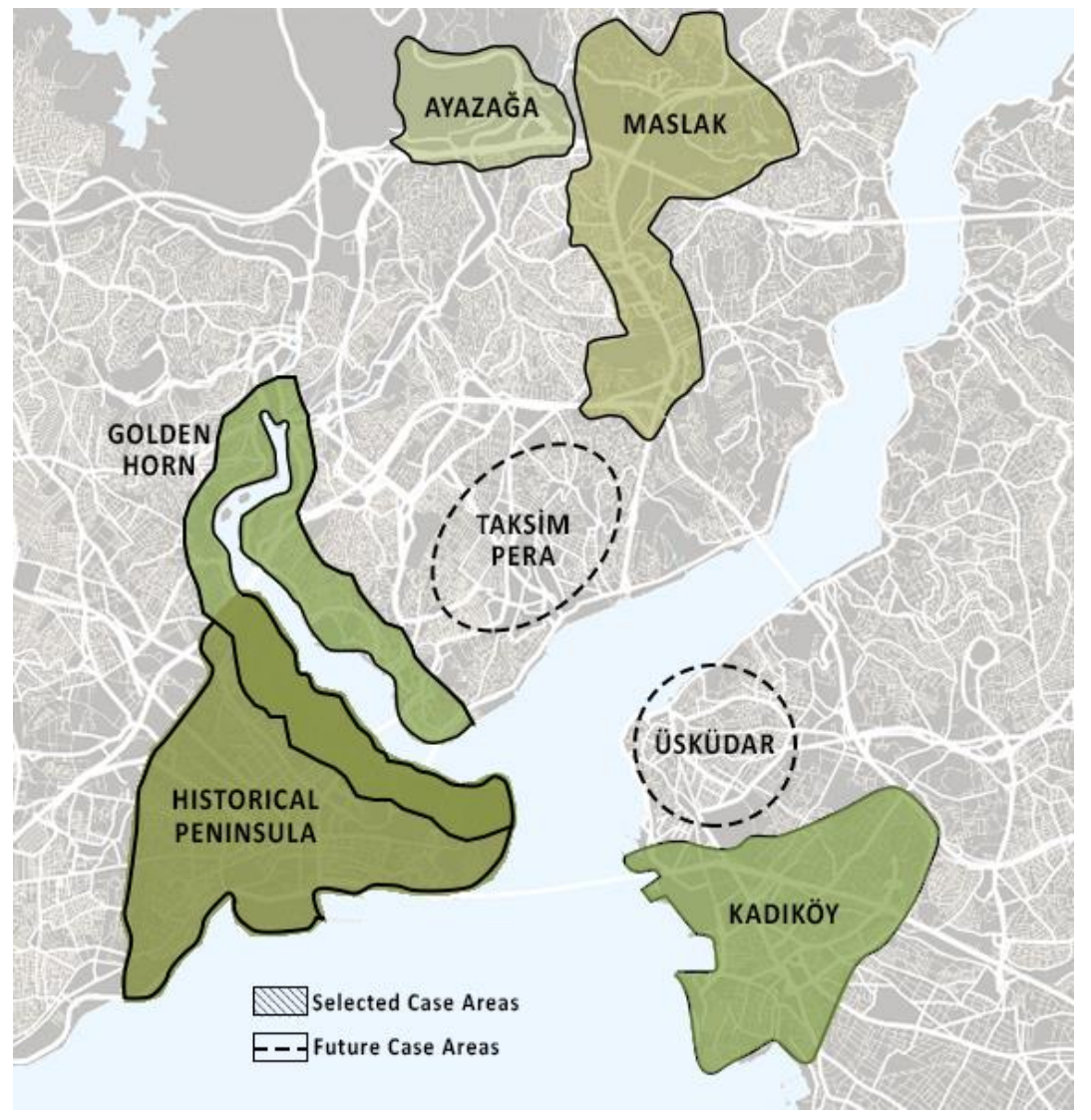

The research methodology for this study is a comparative analysis of various city plans that correspond to significant urban transformation periods (1764 - 2017). The historical maps obtained for the case study areas were categorized as Roman (330 - 476); Byzantine (476 - 1453); Ottoman (1453 - 1800); Westernized (1800 - 1923); and Republican (1923 - Present) as
Figure 1. The selected case study areas of the Istanbul Fringe-Belt analysis 
shown in Fig (2). The selected case study areas were then examined according to these historical periods.

The maps which reflect the urban growth and transformation patterns according to land utilization are listed in Table (2). By using these maps it is possible to better comprehend both the formation and the modification of the fringe-belts in the case study areas.

Figure 2. Selected historical maps of case areas and historical periods

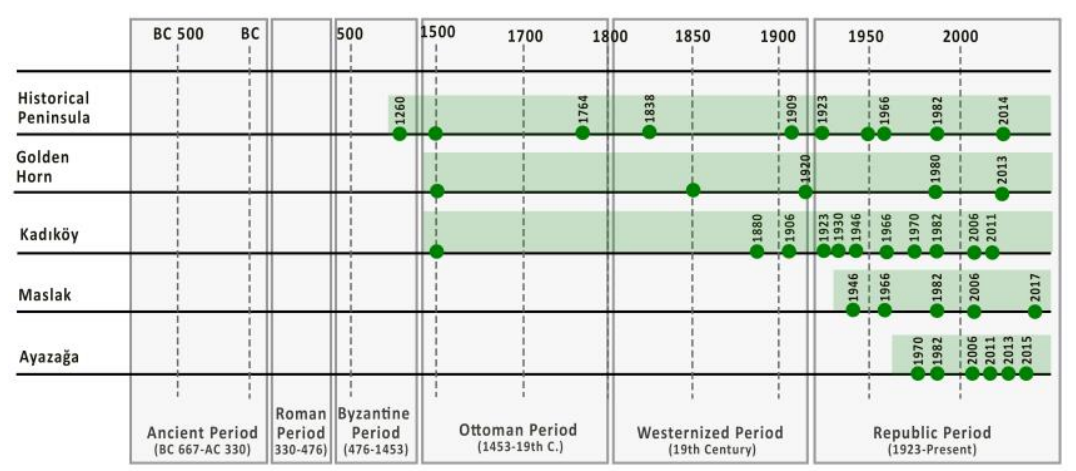

Table 2. Selected historical maps related to the case study areas

\begin{tabular}{|c|c|c|c|c|}
\hline $\begin{array}{l}\text { Historical } \\
\text { Peninsula }\end{array}$ & Kadıköy & Golden Horn & Maslak & Ayazağa \\
\hline $\begin{array}{l}\text { *1260 City Map } \\
\text { *1400s (15 }) \text { City } \\
\text { Map } \\
\text { *1764 City Map } \\
\text { *1838 City Map } \\
\text { *1909 City Map } \\
\text { *1923Pervettich } \\
\text { Maps } \\
\text { *1966 City Map } \\
\text { *1982 City Map } \\
\text { *2014 Satellite Map }\end{array}$ & $\begin{array}{l}\text { *1400s } \\
\left(15^{\text {th }}\right) \text { City } \\
\text { Map } \\
\text { *1880 } \\
\text { Stolpe Map } \\
\text { *1906 Goad } \\
\text { Map } \\
\text { *1922 Gedik } \\
\text { Pasha Map } \\
\text { *1923 } \\
\text { Pervettich } \\
\text { Maps } \\
\text { *1946 } \\
\text { Kadıköy } \\
\text { Satellite } \\
\text { Map } \\
\text { *1966 } \\
\text { Kadıköy } \\
\text { Satellite } \\
\text { Map } \\
\text { *1970 } \\
\text { Kadıköy } \\
\text { Satellite } \\
\text { Map } \\
\text { *1982 } \\
\text { Kadıköy } \\
\text { Satellite } \\
\text { Map } \\
\text { *2011 } \\
\text { Kadıköy } \\
\text { Satellite } \\
\text { Map } \\
\text { Madion }\end{array}$ & $\begin{array}{l}\text { *1400s }\left(15^{\text {th }}\right) \text { City } \\
\text { Map } \\
\text { *1853 And } 1860- \\
1970 \text { City Maps } \\
\text { *1913 German } \\
\text { Blues Map } \\
\text { *1923Pervettich } \\
\text { Maps } \\
\text { *1978 Land } \\
\text { Utilization Maps Of } \\
\text { Golden Horn } \\
\text { *2013 Land } \\
\text { Utilization Map Of } \\
\text { Golden Horn }\end{array}$ & $\begin{array}{l}* 1946 \\
\text { Maslak } \\
\text { Satellite } \\
\text { Map } \\
\text { *1966 } \\
\text { Maslak } \\
\text { Satellite } \\
\text { Map } \\
\text { *1982 } \\
\text { Maslak } \\
\text { Satellite } \\
\text { Map } \\
\text { *2006 } \\
\text { Maslak } \\
\text { Satellite } \\
\text { Map } \\
\text { *2017 } \\
\text { Maslak } \\
\text { Satellite } \\
\text { Map }\end{array}$ & $\begin{array}{l}\text { *1970 } \\
\text { Ayazağa } \\
\text { Satellite } \\
\text { Map } \\
\text { *1982 } \\
\text { Ayazağa } \\
\text { Satellite } \\
\text { Map } \\
\text { *2006 } \\
\text { Ayazağa } \\
\text { Satellite } \\
\text { Map } \\
\text { *2011 } \\
\text { Ayazağa } \\
\text { Satellite } \\
\text { Map } \\
\text { *2013 } \\
\text { Ayazağa } \\
\text { Satellite } \\
\text { Map } \\
\text { *2015 } \\
\text { Ayazağa } \\
\text { Satellite } \\
\text { Map }\end{array}$ \\
\hline
\end{tabular}




\section{ISTANBUL: HISTORICAL EVOLUTION}

The historic development of Istanbul consists of different phases and stratification from ancient times until today. (Kubat, 1999). The main periods of the city's development are its ancient Roman, Byzantine, Ottoman, Westernized and Republican phases. The city dates back 3 thousand years and for nearly 16 centuries it was consecutively the capital of the Roman, Byzantine, and Ottoman Empires.

Pre-Roman and Roman Periods: The first settlement where Istanbul now stands was established on a peninsula (the "Historical Peninsula" today) surrounded on three sides by the Marmara Sea, the Bosphorus, and the Golden Horn. Founded in the 7th century BC, the city was primarily Greek and was called "Byzantion". It developed over time and later fell under the rule of the Roman Empire. During this period, with the declaration of the east as the administrative center of the Empire, the city became a center of culture and politics. There is no numerical area size data for the pre-Roman period, however, it can be said that it remained as a small commercial city. Sources show that it occupied an area of approximately 140 hectares during the Roman period (Kuban, 1996). The first defensive wall was built by Septimius Severus; it stretched for about $5 \mathrm{~km}$ and had 27 towers. This wall was later demolished by Constantine I and another was built $3 \mathrm{~km}$ to the west to improve the security of the city (IBB, 2005).

Byzantine Period: The city of Byzantium became the center of the Byzantine Empire after the Roman Empire lost political and economic power and divided into two in 395 . The eastern capital became known as "Nova Roma" (New Rome) and was officially renamed Constantinople in 330 Fig (3), in honor of the emperor (Kuban, 1996). This period saw the city flourish in terms of both a greater urbanism and major architectural works. Under the reign of Theodosius II, the population increased, its area expanded from $6 \mathrm{~km}^{2}$ to $14 \mathrm{~km}^{2}$, and it became necessary for it to be administratively divided into 14 regions and 322 sub-units. 
Figure 3. Byzantine Constantinople Map, 1260 (Harvard Map Collection)

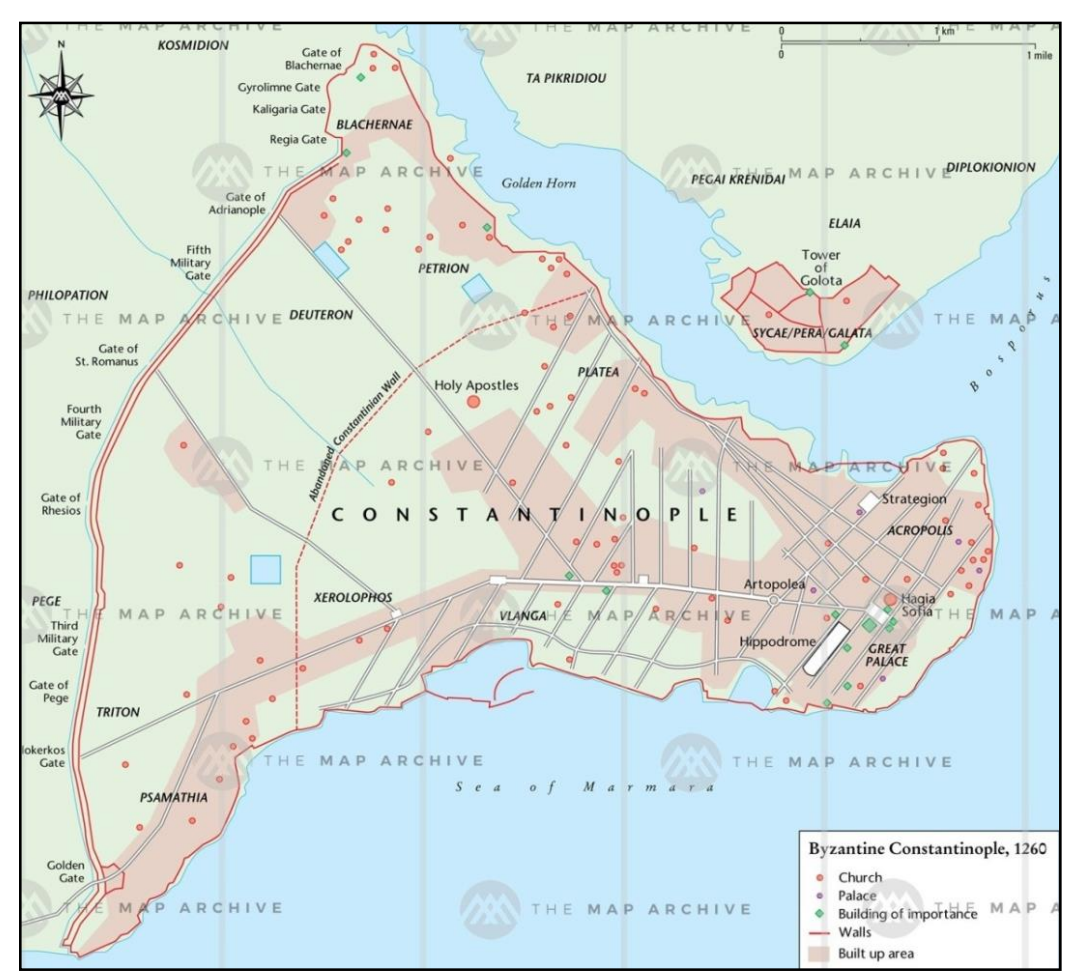

Ottoman Period: The city was conquered in 1453 by the Ottoman army under the command of Fatih Sultan Mehmet and became the capital of the Ottoman Empire in 1457. Following this, there were changes made to both its physical and social structures (Kuban, 1996). Renamed Istanbul, the city which had previously developed according to a typical Roman city form, now came under the influence of Islamic culture. The magnificent buildings and mosques (Topkapı Palace, Sultanahmet Mosque etc.) were built on the hills overlooking the Golden Horn, fundamentally changing the city's appearance. The 16th and 17th centuries under Ottoman rule were among the brightest periods of Istanbul. During these centuries, the city spread across both shores of the Golden Horn and the Bosphorus to Galata, Pera, Üsküdar, and Kadıköy Fig (4). As the 18th century progressed, however, it began to become impoverished, and its urban structure was later damaged and irrevocably changed by fires in the 19th century. The street patterns of many districts within the Historical Peninsula (Aksaray, Unkapanı, Fener, and Balat) lost their original structure. Following this, as mentioned by Kuban (Kuban, 1996), the size and number of green areas decreased as they were converted into residential districts. 


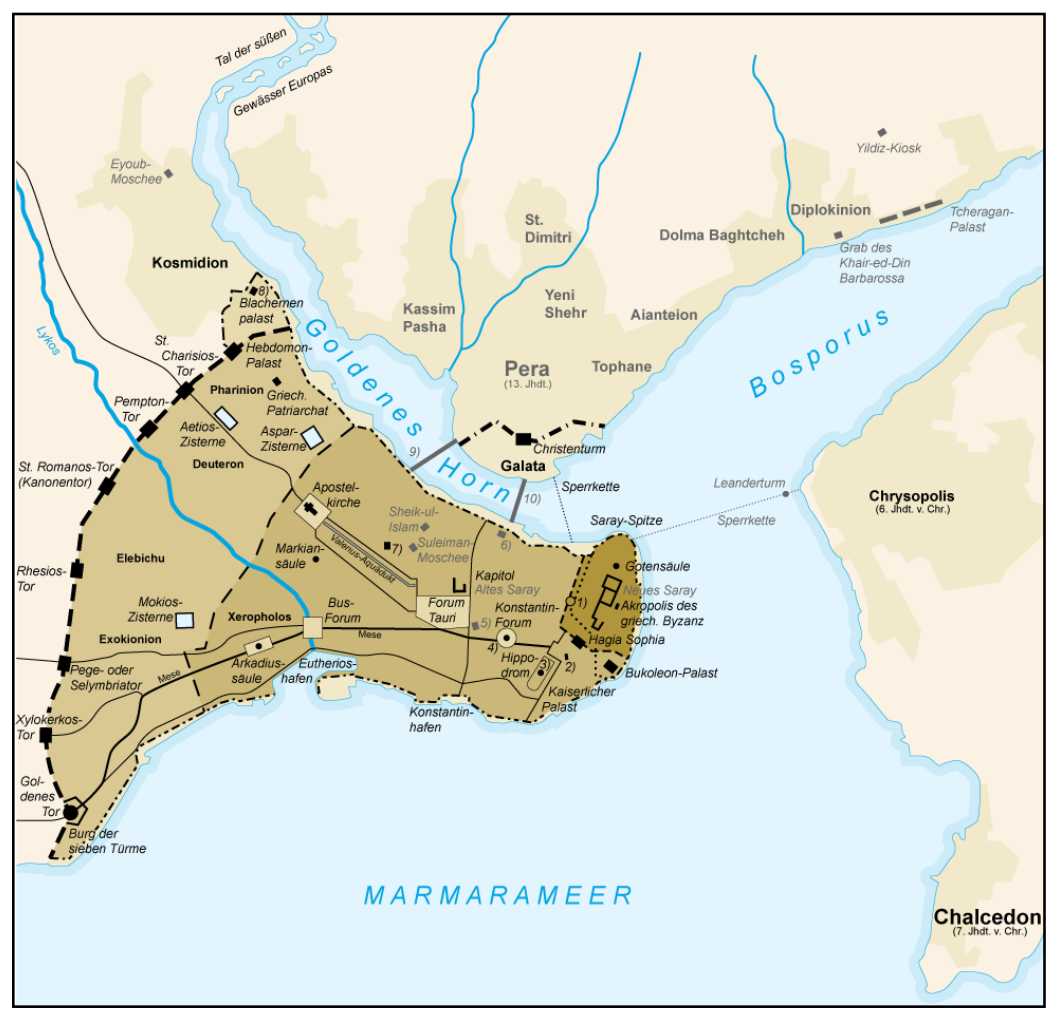

Figure 4. Constantinople in 15th Century (German Kartenwerkstatt Map)

Westernized Period: The 19th century was a period when the Ottoman economy became open to capitalist relationships and the first planning studies were carried out. Westernization brought great changes to the city; the Golden Horn was given over to industrialization processes, the transportation system was improved, and many major development activities were undertaken. With the construction of the Sirkeci-Edirne and Haydarpaşa-Izmit railways, commuter trains started to operate and suburban settlements began to grow outside the center (IBB, 2009).

Republican Period: In the first years of the Republican period, the growth rate of the city population decreased and several reconstruction initiatives were started in response. However, the plans prepared by European urban planners and architects had major effects on the spatial structure of the city. For instance, although Prost's plan (1937) had a conservative attitude toward the city's cultural heritage and its natural landscape, it also intervened radically on its historical fabric. The most important aspect of this plan was the development of medium- and largescale industries on the shores of the Golden Horn and the construction of state-owned factories and warehouses on the shores of the Bosphorus (Kubat\&Hazar, 2018).

As a result of these initiatives, migration to the city increased once more, leading to the development of illegal housing areas. The first migration wave settled around the Golden Horn and the industrial 
areas outside the city walls. Thus, Kağıthane and Zeytinburnu became the nuclei of the first illegal housing areas (settlements and structures built without permission or land titles). The Istanbul Industrial Plan of 1955 froze some of the industrial development of the Golden Horn. The aim of this plan was to decentralize industries by relocating them to the periphery (Topkapi-Rami and Levent). However, this decision led to the creation of yet more illegal housing. In the 1950s, the Kağithane illegal housing area had grown large enough for it to become the third-largest in the city, and the formation of new industrial areas caused other non-controlled areas such as Halkall, Maltepe, and Kartal to also become sites for illegal housing. By the mid-1950s, Istanbul had spread over an area that extended to Yeşilköy (the location of Atatürk Airport) in the west, Levent (a high-density residential area) to the north, and Bostancı (another residential area) on the Anatolian side (IBB, 2009). Additionally, the development of new apartment buildings close to the illegal housing areas also became a problem during this period. In 1965, with the Law of Floor Ownership (condominium), primary empty spaces and later green spaces, parks and playgrounds were transformed into apartment buildings. Parallel to this, the acceleration of the industrialization process also continued the rise in unregulated and illegal housing, and by 1962, residents in illegal housing (squatter settlements) accounted for $40 \%$ of Istanbul's urban population.

In the 1970s, there were over 2 million people living in Istanbul, and in 1980, the population of the city had reached 3 million, mostly spread across three regions: the Historical Peninsula, Karaköy-Beyoğlu and Üsküdar-Kadıköy (Kubat \&Hazar, 2018). In the 1980s, industries around the Golden Horn were moved to the periphery in a move toward decentralization, and expropriation projects and coastal arrangements were carried out in many districts of the city. In 1980, the first Istanbul Metropolitan Area Master Plan was prepared and approved by the Ministry of Reconstruction and Settlement. This was produced at a scale of 1 / 50,000 and was intended to be complete by 1995 .

As a result of population movements and settlement tendencies in the city in the 1990s, it was observed that development was moving in the east-west direction. This was partly due to new and rapidly developing industrial areas which had led to the formation of more illegal settlements in their surrounding areas, and also because of increased reconstruction rights which resulted in further increases in population. In addition, the bridges built across the Bosphorus (Bosphorus Bridge-1973; Fatih Sultan Mehmet Bridge-1988; Yavuz Sultan Selim Bridge-2016) have each 
created new development axes, and one major result of this has been the movement of the CBD from the Historic Peninsula towards Maslak.

\section{APPLICATION OF THE METHODOLOGY}

\section{The Fringe-Belts of Istanbul}

The initial settlements within the region were established on the Historical Peninsula (European side) and in the Kadıköy region (Anatolian side) during the Roman period. The first fringe-belt formation and fixation lines occurred at the tip of the Historical Peninsula (where today's Topkapi Palace is located) during the Ottoman period (Fig 5a). While a study of the Chalcedon archeological site (where Kadıköy now stands) shows that it did not reflect the fixation characteristics of its historical period (Fig $5 a-b)$, and disappeared over time. The fixation lines of the sea walls and land walls of the peninsula date back to before the Byzantine Empire (Fig 5b).

The Roman Severius walls and Byzantine Constantinian walls of the Historical Peninsula no longer exist, and both have long-since lost their fringe characteristics. However, these historical walls can be accepted as fossil or ghost fixation lines as major transportation axes have been built where they once stood (Ataturk Boulevard follows the route of the Constantinian wall and Ankara Street follows that of the Severius wall respectively).

(Fig 5b)

Although the fringe-belts of Kadıköy and the Historical Peninsula were mostly consolidated during the Ottoman period, there are also alienated and expanded areas within the fringe areas of these districts (Fig 5c). During the Ottoman period, the settlement on the peninsula spread to the opposite shore of the Golden Horn after the construction of the Galata Bridge. (Fig 5c)

During the Westernization period, the Maslak and Ayazağa regions, which were in the urban periphery in the previous periods, were redeveloped from agricultural areas to industrial and military zones. On the Anatolian side, many of Kadıköy's fringe-belts were transformed from open spaces and low density residential areas to more intensive residential and commercial uses (Fig 5d).

Most of the fringe-belt areas in the Golden Horn district have been redeveloped during the current Republican period. However, characteristically fringe-belt areas have also been consolidated in both the Historical Peninsula and the Kadıköy district (Fig 5e). The Maslak region has also undergone a FB alienation process that 
started due to its subsequent redevelopment (transformation) from industrial use to a CBD Fig (5e).

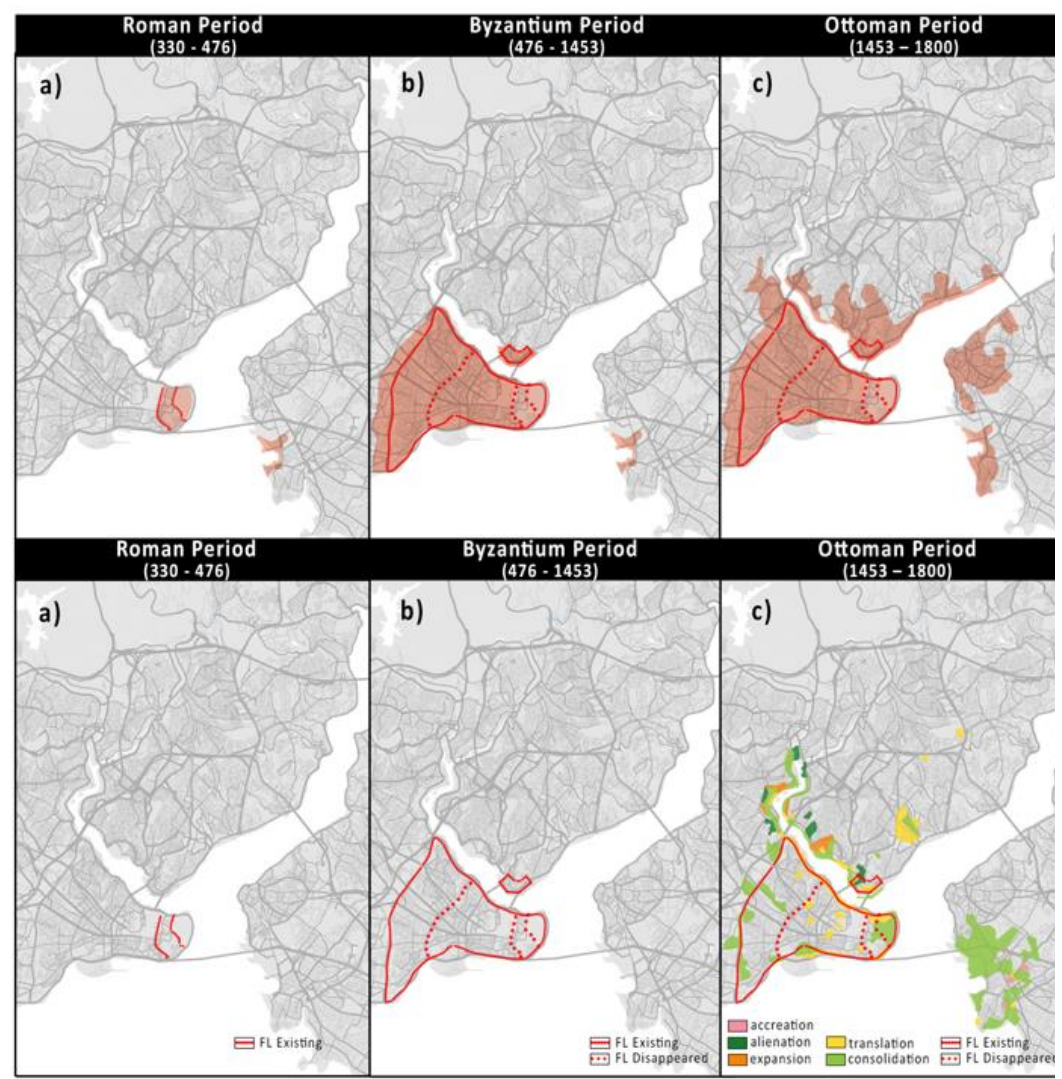

Figure 5. Fixation line formation and fringe belt modification process of İstanbul (prepared by authors; the historical maps mentioned in Table 2)

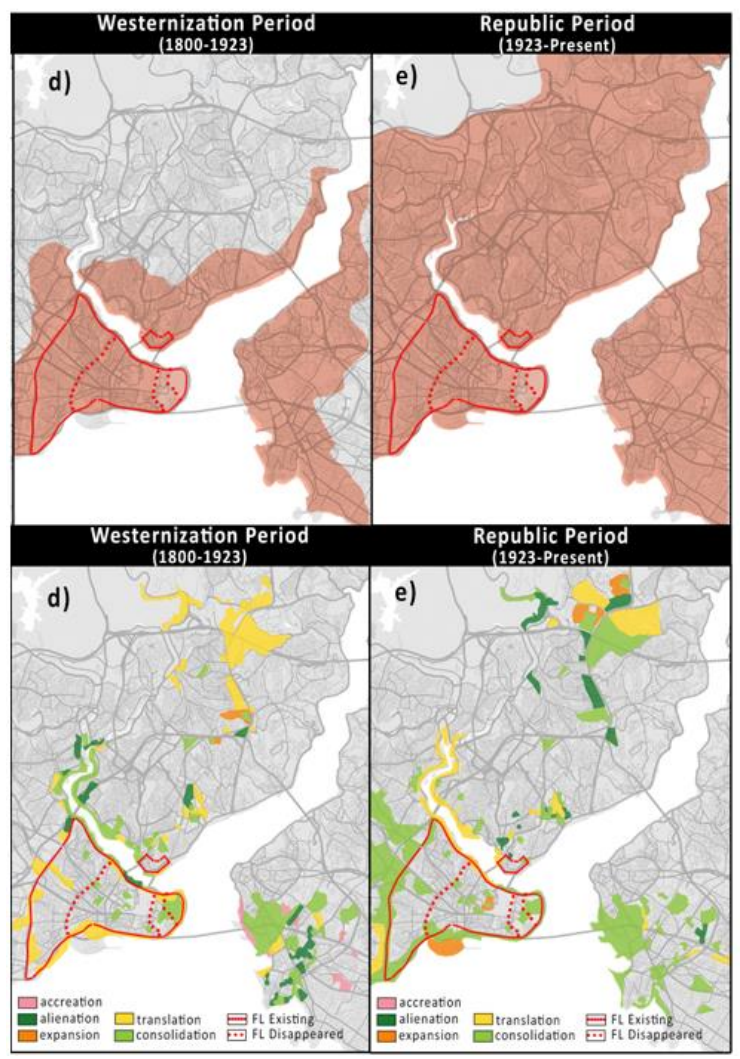


Exploring the Fringe-Belt Phenomenon in a Multi-Nuclear City: The Case of Istanbul

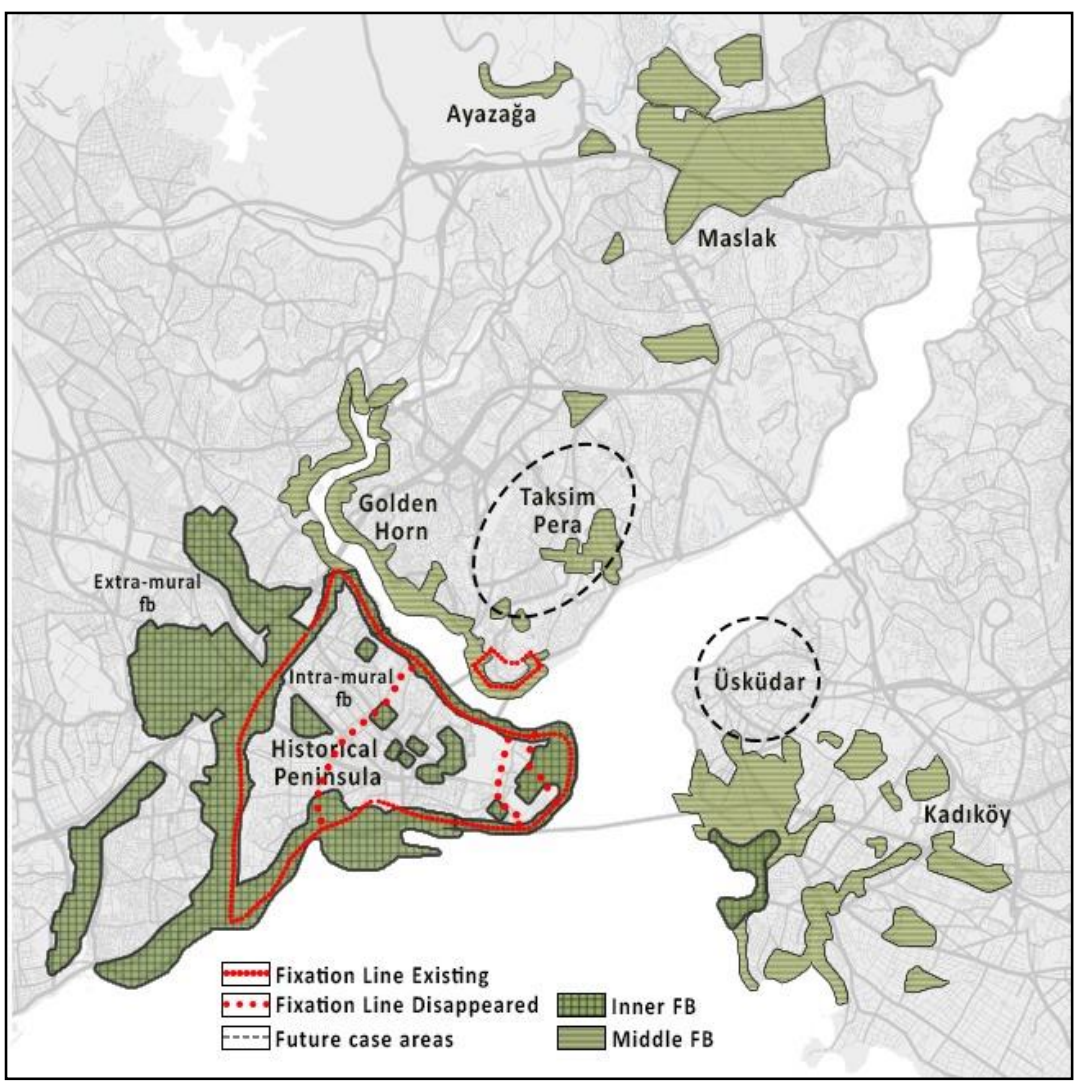

\section{Inner Fringe Belts: Historical Peninsula}

The Theodosius walls (land walls) and sea walls of the historical peninsula created a continuous fringe belt zone. These continuous green belts included agricultural areas, cemeteries and urban parks.

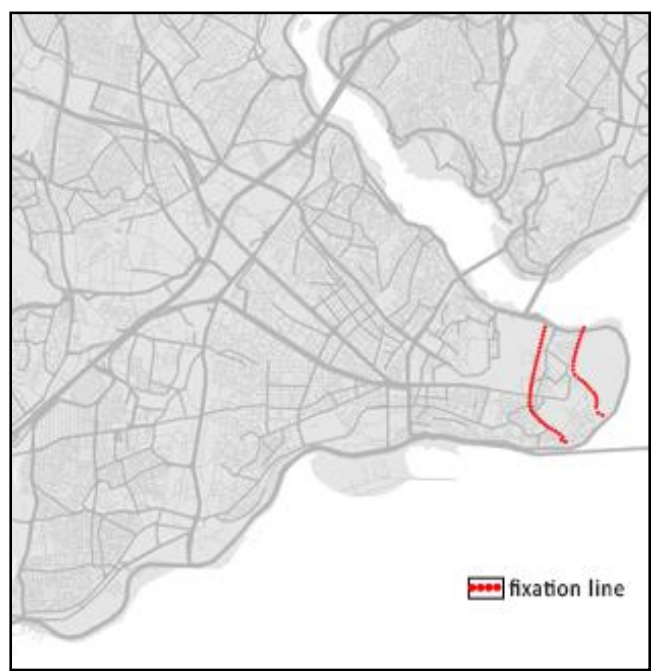

Figure 6. Inner and Middle Fringebelt areas of Istanbul (prepared by the author; FB maps in Figure 5)
Figure 7. Fixation line formation process of the Historical Peninsula during the Roman period (330-476) 
Figure 8. Fixation line formation process of the Historical Peninsula during the Byzantine phase (4761453)

Figure 9. Fringe-belt modification process of the Historical Peninsula during the Ottoman period (1453 1800)

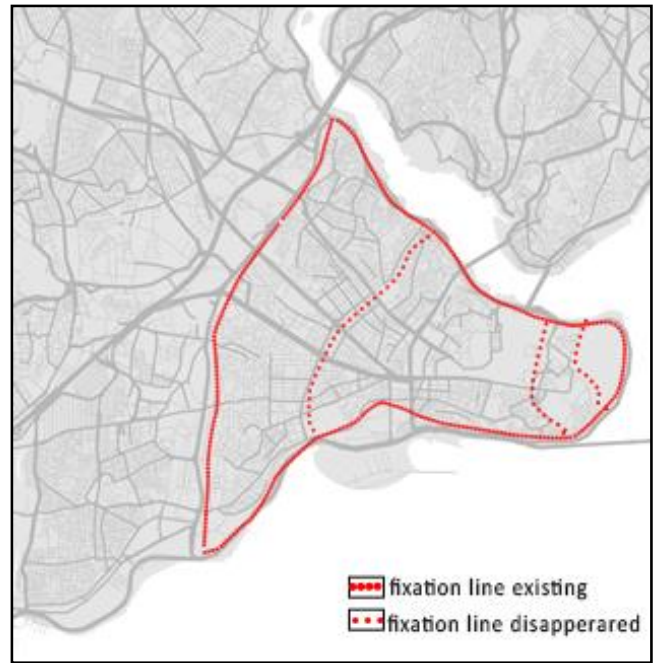

Detailed analyses of the maps reveal that the fixation line of the city Istanbul was developed throughout the Roman period and Byzantine periods. Firstly, the Severius wall and later the Constantinian and Theodosius II walls were constructed. The Constantinian wall was demolished during the Byzantine period Fig (7- 8).

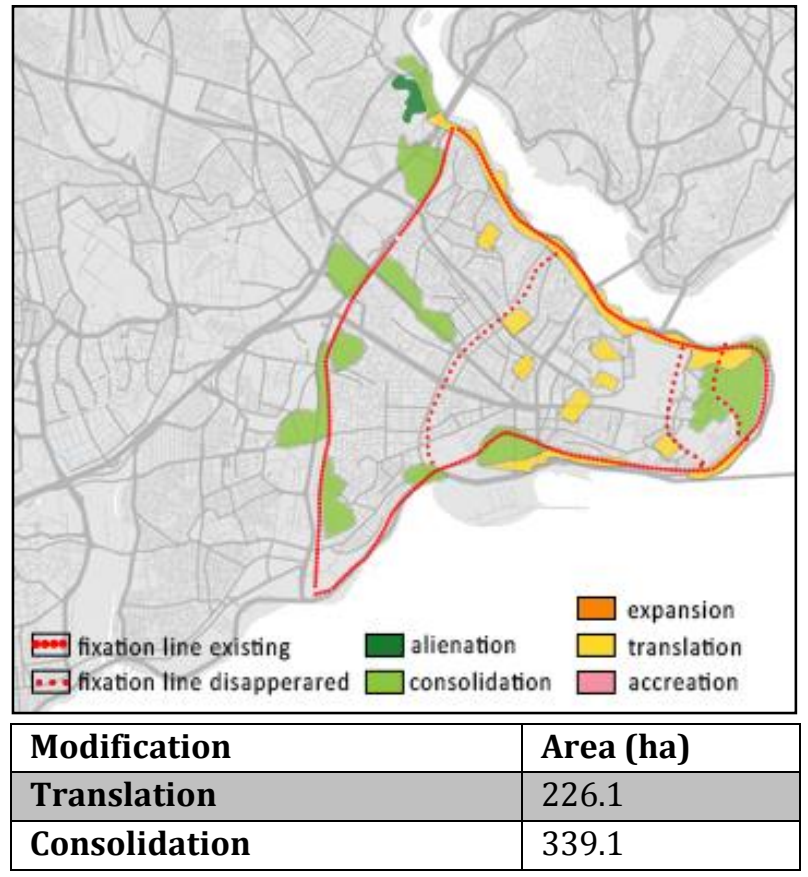

During the Ottoman period; Open spaces, common entities and institutional areas were consolidated around the fixation line, however, the waterfront residential areas were given over to industrial and institutional functions. Many inland residential areas were also taken for institutional use, as in Fig (9). 


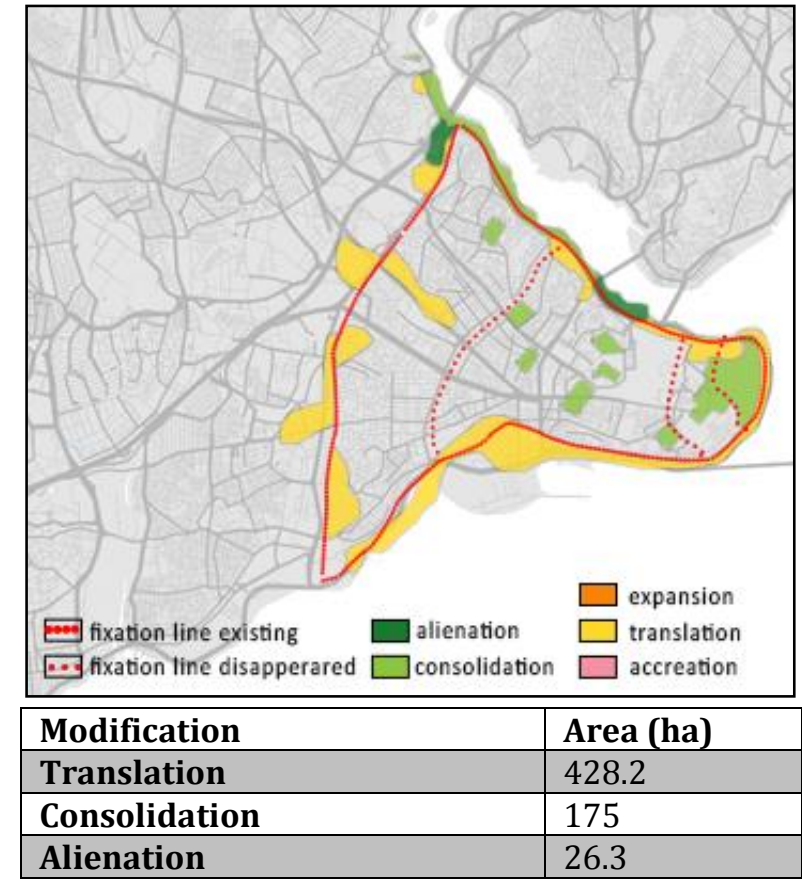

During the Westernization period, most Inner fringe-belt uses underwent processes of translation. In general, these areas were changed from open spaces to institutional and industrial areas (Fig. 10). While fringe-belt uses were consolidated in inland areas, and partly in waterfront areas, some of the industrial zones were given over to commercial use (FB alienation).

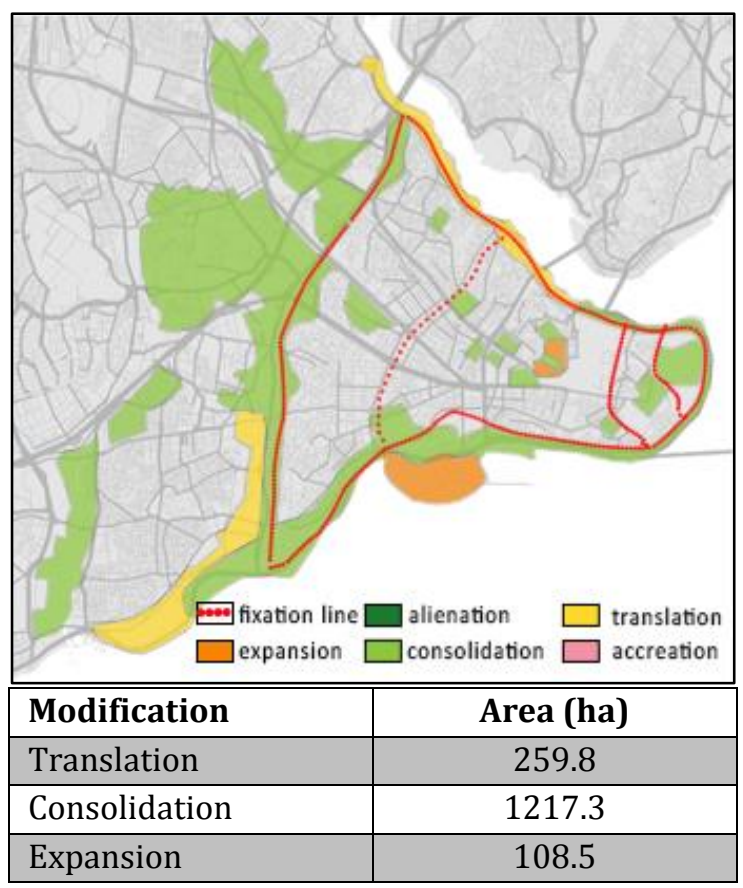

During the current Republican period, fringe-belt usage around the fixation line, especially around the Theodosius II wall, has increased and has mostly been consolidated. Religious sites; such as the Süleymaniye Mosque, the Hagia Sophia, the Sultanahmet
Figure 10. Fringe-belt modification process of Historical Peninsula during the Westernization period (18001923)

Figure 11. Fringe-belt modification process of the Historical Peninsula during the Republican period (1923Present) 
Mosque and the İstanbul University Campus (which was ones an Ottoman Palace); were also consolidated within larger areas in the internal structure of the peninsula. At the waterfront, fringe-belt areas have been expanded due to the Yenikapı landfill project Fig (11).

Figure 12. Land use of the current Inner Fringe Belt area on the Historical Peninsula (prepared by author)

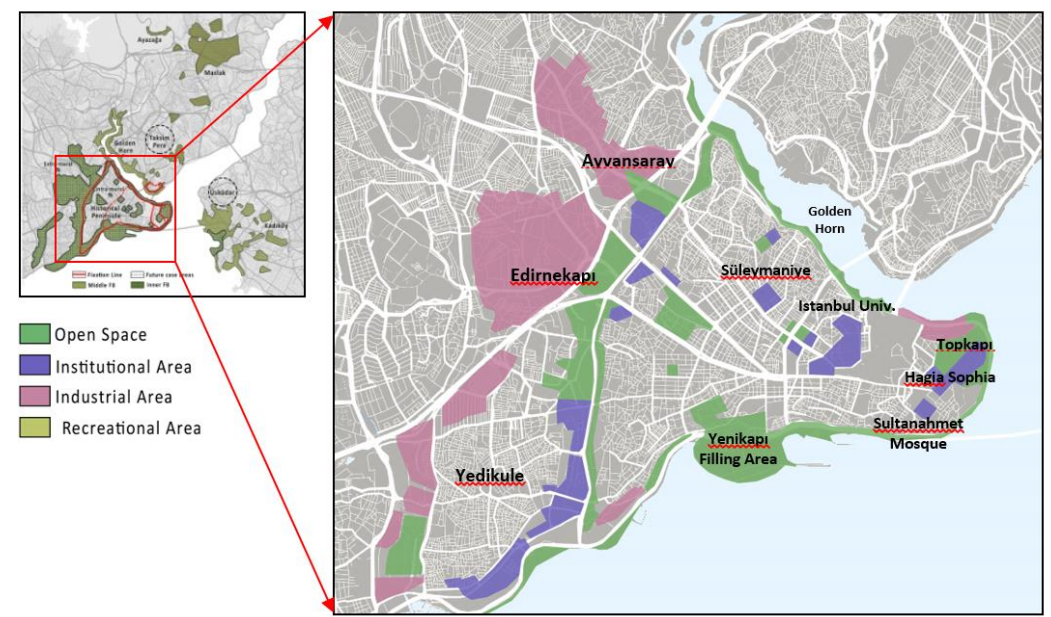

From these observations, it can be determined that the land uses in the current inner fringe-belt area are; empty lots, green areas, cemeteries, farmlands, industrial areas, storage, institutional areas, religious and monumental buildings Fig (12). The fringebelt change process of the Historical Peninsula and the elements of the fringe-belt are shown in Table (3).

Table 3. The fringe-belt development process of the Historical Peninsula and the elements of the fringe-belt (prepared by author)

\begin{tabular}{|c|c|c|}
\hline \multicolumn{3}{|c|}{ INNER FRINGE BELTS } \\
\hline \multirow[t]{2}{*}{ Periods } & \multicolumn{2}{|c|}{ Historical Peninsula } \\
\hline & $\begin{array}{l}\text { Change } \\
\text { Process }\end{array}$ & FB Elements \\
\hline $\begin{array}{c}\text { B.C. } 667 \text { - } \\
\text { A.C.330Byzantion/Chalcedon }\end{array}$ & $\begin{array}{l}\text { Byzantion as a } \\
\text { Greek city }\end{array}$ & $\begin{array}{l}\text { Monumental } \\
\text { structures, } \\
\text { (Institutional areas), } \\
\text { ports and first city } \\
\text { walls } \\
\text { FB formation- } \\
\text { fixation } \\
\text { line(Ancient Wall) }\end{array}$ \\
\hline 330 - 476 Roman Empire & $\begin{array}{l}\text { The eastern } \\
\text { administrative } \\
\text { center of the } \\
\text { Roman Empire }\end{array}$ & $\begin{array}{l}\text { Harbors, aqueducts, } \\
\text { new city walls, } \\
\text { temples, forum, low } \\
\text { density residential } \\
\text { areas, monumental } \\
\text { structures } \\
\text { (Institutional areas) } \\
\text { FB formation- } \\
\text { fixation line } \\
\text { (Septimius Severius } \\
\text { wall) }\end{array}$ \\
\hline
\end{tabular}




\begin{tabular}{|c|c|c|}
\hline 476 - 1453 The Byzantine Empire & $\begin{array}{l}\text { Plague epidemic, } \\
\text { occupation, looting, } \\
\text { poverty, Ottoman } \\
\text { siege, } \\
\text { Reconstruction of } \\
\text { Hagia Sophia }\end{array}$ & $\begin{array}{l}\text { Monumental } \\
\text { structures, a new } \\
\text { wall system, } \\
\text { forum, harbors } \\
\text { FB formation- } \\
\text { fixation line } \\
\text { (Constantine \& } \\
\text { Theodosius II } \\
\text { walls) }\end{array}$ \\
\hline 1453 - 19th c. Ottoman Empire & $\begin{array}{l}\text { Islamic influence, } \\
\text { population growth, } \\
\text { spreading outside } \\
\text { the city walls, new } \\
\text { settlement } \\
\text { arrangements, } \\
\text { changes in the } \\
\text { silhouette of the } \\
\text { region }\end{array}$ & $\begin{array}{l}\text { Monumental } \\
\text { structures, } \\
\text { recreation areas, } \\
\text { cemeteries, farms } \\
\text { and gardens, low } \\
\text { density residential } \\
\text { areas, religious } \\
\text { areas } \\
\text { FB modification } \\
\text { (translation) }\end{array}$ \\
\hline $\begin{array}{l}\text { 19th c. Ottoman Empire } \\
\text { (Westernization) }\end{array}$ & $\begin{array}{l}\text { Improvements in } \\
\text { transportation, Fire } \\
\text { disasters, new } \\
\text { institutions, } \\
\text { Moltke's plan }\end{array}$ & $\begin{array}{l}\text { Barracks, railways, } \\
\text { institutional areas, } \\
\text { low-density } \\
\text { residential areas, } \\
\text { cemeteries, farms } \\
\text { and gardens } \\
\text { FB modification } \\
\text { (translation) }\end{array}$ \\
\hline $\begin{array}{l}\text { The Republic and the 20th c. Modern } \\
\text { City }\end{array}$ & $\begin{array}{l}\text { Decrease in } \\
\text { population after } \\
\text { WW1, work of } \\
\text { foreign planners } \\
\text { and architects } \\
\text { (1930s), demolition } \\
\text { of historical } \\
\text { monumental } \\
\text { structures for new } \\
\text { roads, increase in } \\
\text { land values, } \\
\text { apartmentization }\end{array}$ & $\begin{array}{l}\text { Railways, stations, } \\
\text { monumental } \\
\text { structures, illegal } \\
\text { housing areas, } \\
\text { institutional areas, } \\
\text { low-density } \\
\text { residential areas, } \\
\text { cemeteries, farms } \\
\text { and gardens } \\
\text { FB modification } \\
\text { (translation, } \\
\text { alienation) }\end{array}$ \\
\hline Metropolitan city (After 2000) & $\begin{array}{l}\text { Rapid population } \\
\text { growth, } \\
\text { reconstruction } \\
\text { amnesties, } \\
\text { increases in illegal } \\
\text { housing areas, } \\
\text { tramway, light } \\
\text { metro, subway. }\end{array}$ & $\begin{array}{l}\text { New institutional } \\
\text { uses (universities, } \\
\text { mosques), illegal } \\
\text { housing areas, low } \\
\text { density residential } \\
\text { areas, cemeteries, } \\
\text { farms and gardens } \\
\text { FB modification } \\
\text { (translation, } \\
\text { consolidation) }\end{array}$ \\
\hline
\end{tabular}

For the inner fringe-belt analysis, three sample areas, Ayvansaray (at the northern part of the Theodosius walls), Edirnekapı (the gate of the Theodosius walls), and Yenikapı (at the southern tip of the Theodosius walls) were examined in detail. The plot-based changes over the years were investigated through the studies conducted in Ayvansaray (Fig. 13). The analysis revealed a remarkable increase in the number of buildings on empty lots in Edirnekapı Fig (14), and it was determined that farmland was transformed into residential areas during the urban growth process of the Yenikapı district (Fig. 15). 
Figure 13. 1929-2016 plot-based change in Ayvansaray (prepared by author)

Figure 14. 928-2016 plot change in Edirnekapi (prepared by author)

Figure 15. 1830-2010

transformation of the farmlands in Yedikule (prepared by author)
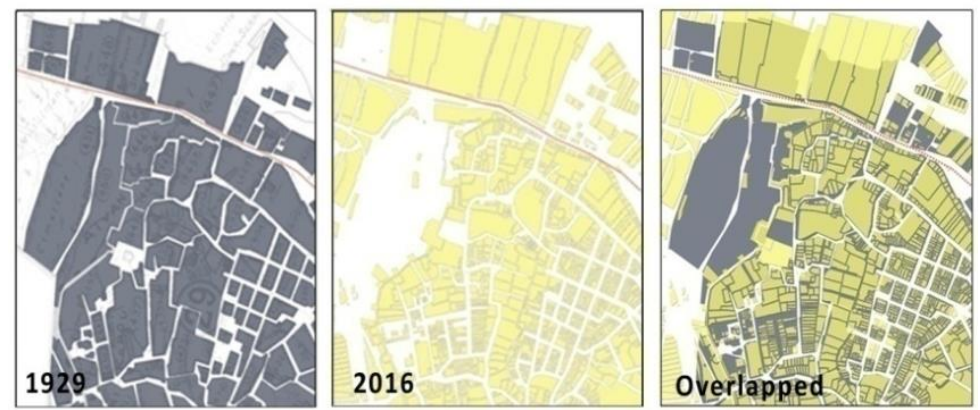

\begin{tabular}{|l|r|c|l|}
\hline $\begin{array}{l}\text { Plot } \\
\text { Pattern }\end{array}$ & $\begin{array}{l}\text { Number of } \\
\text { Plot }\end{array}$ & $\begin{array}{l}\text { Min. Plot } \\
\text { Area }\end{array}$ & $\begin{array}{l}\text { Max. } \\
\text { Area }\end{array}$ \\
\hline $\mathbf{1 9 2 9}$ & 77 & $122 \mathrm{~m}^{2}$ & $22.400 \mathrm{~m}^{2}$ \\
\hline $\mathbf{2 0 1 6}$ & 1072 & $38 \mathrm{~m}^{2}$ & $12.460 \mathrm{~m}^{2}$ \\
\hline
\end{tabular}
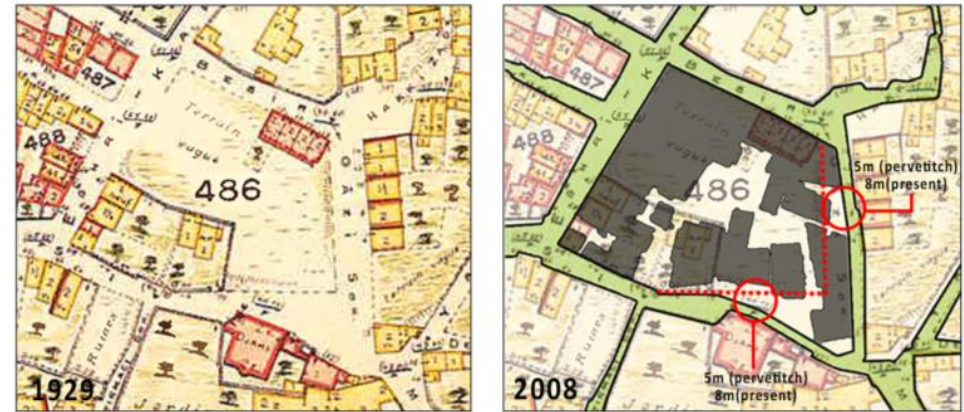

\begin{tabular}{|l|c|c|}
\hline Change & $\begin{array}{c}\text { Pervettich } \\
\text { (1929) }\end{array}$ & $\begin{array}{c}\text { Present } \\
\text { (2008) }\end{array}$ \\
\hline Blocks & 2685 & 3211 \\
\hline $\begin{array}{l}\text { Total building floor } \\
\text { area }\end{array}$ & 360 & 2256 \\
\hline FAR & 0,10 & 0,70 \\
\hline
\end{tabular}
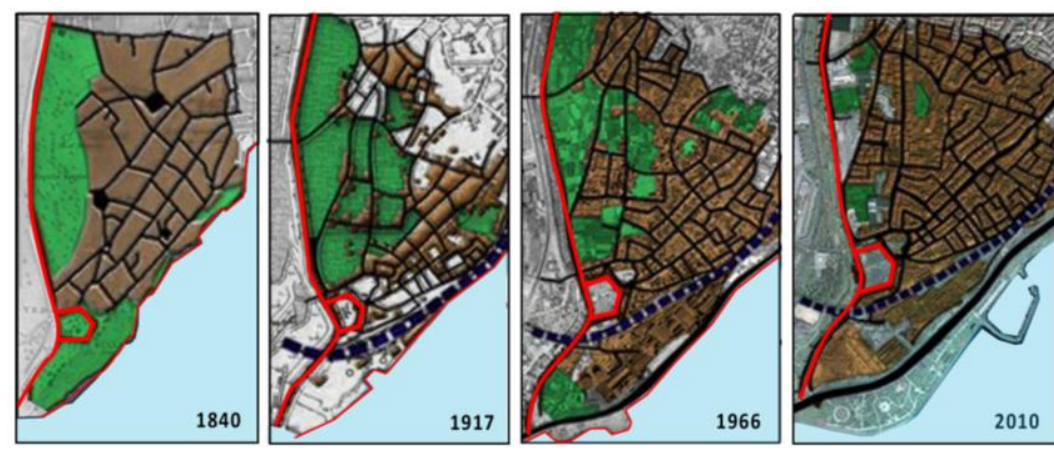

\section{Middle Fringe Belts (MFB)}

The conducted analysis of the inner fringe-belt around the historical city walls, and its transformation into the middle fringebelt area of Istanbul can be determined by several common factors. For this reason, separate "district based" analyses are essential for middle fringe-belt studies of Istanbul as the city is a multi-centered metropolis and is therefore very different to its counterparts in Europe. 

of Istanbul

\section{Golden Horn as a Middle Fringe Belt (MFB):}

The open spaces, low density residential areas, and institutional areas were consolidated during the Ottoman period. However, some of these areas transformed into industrial zones following changes to planning policies (Fig. 16).

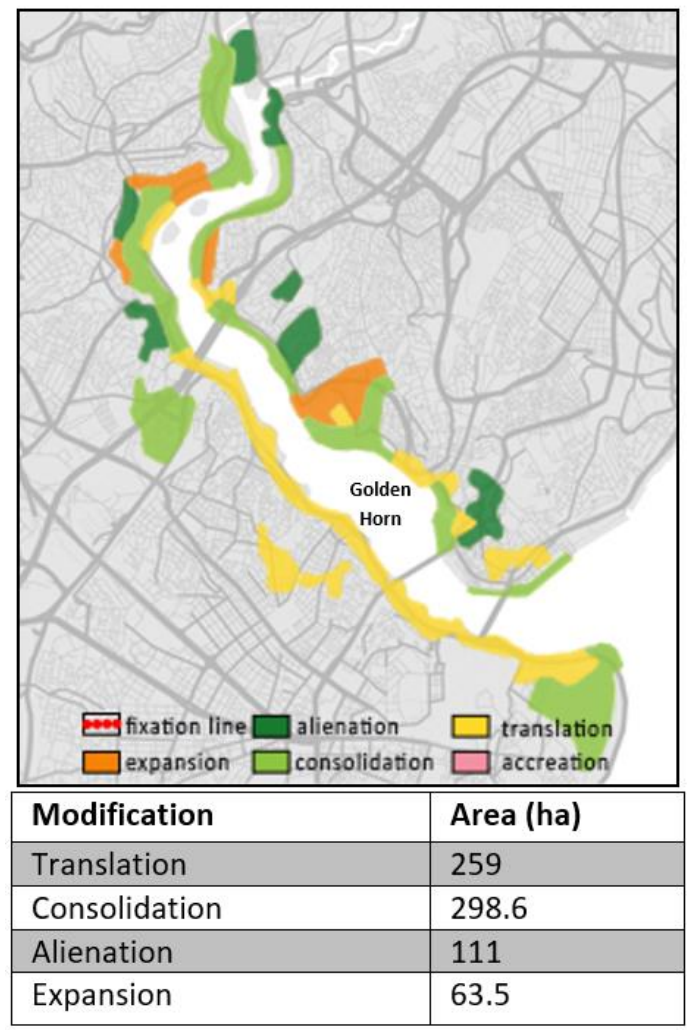

Figure 16. Fringe belt modification process of the Golden Horn during the Ottoman Period (1453 - 1800)

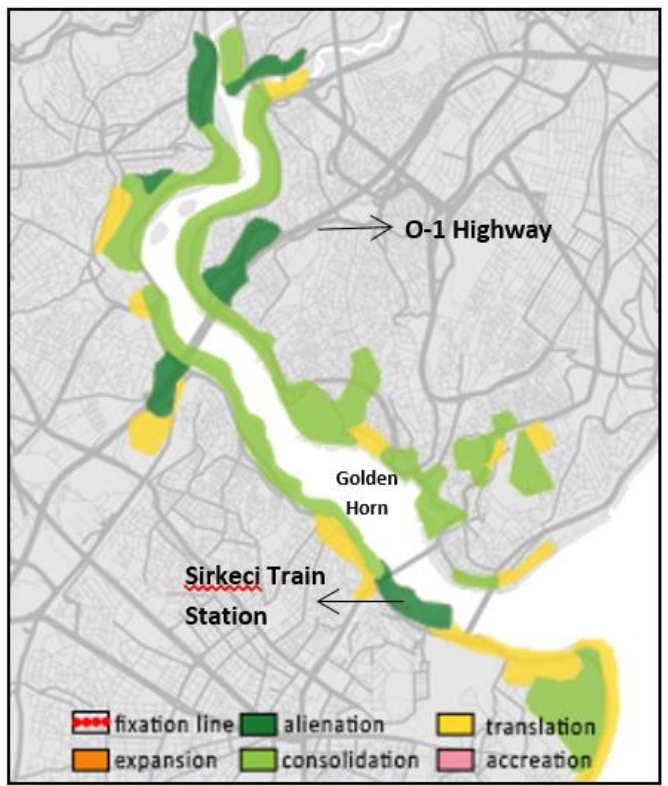

\begin{tabular}{|l|l|}
\hline Modification & Area (ha) \\
\hline Translation & 171.3 \\
\hline Consolidation & 387.2 \\
\hline Alienation & 93 \\
\hline
\end{tabular}

Figure 17. Fringe belt modification process of the Golden Horn during the Westernization Period (1800-1923) 
Although the consolidation process can be seen in the Golden Horn, the reconstruction activities that were accelerated during the Westernization period also caused changes within these areas. Open spaces and low density residential areas were transformed into institutional areas (such as Sirkeci Railway Station) (Fig. 17). At the same time, the cemeteries and low density residential areas lost their character and became alienated after the construction of a major new road (the 0-1 Highway).

Figure 18. Fringe belt modification process of the Golden Horn during the Republican period (1923-Present)

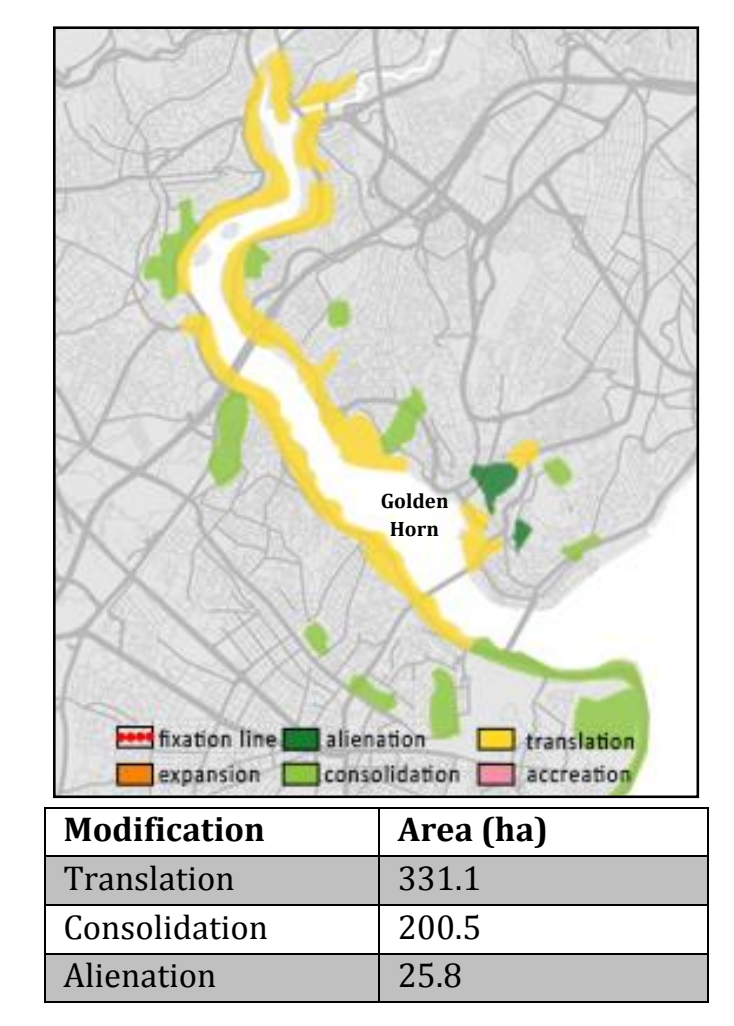

During the Republican period, the fringe-belt areas of the Golden Horn were redeveloped into recreational and/or cultural areas due to the policy of industrial decentralization (Fig. 18). In addition, cemeteries, institutional areas, recreational areas, and some industrial areas were consolidated during this period.

From these observations, it can be determined that the land use in the current middle fringe-belt area of the Golden Horn consists of recreational areas, cemeteries, industrial areas, ports, institutional areas, and cultural areas (Fig. 19). The fringe-belt change process in the Golden Horn and the elements of the fringebelt are shown in Table 4. 


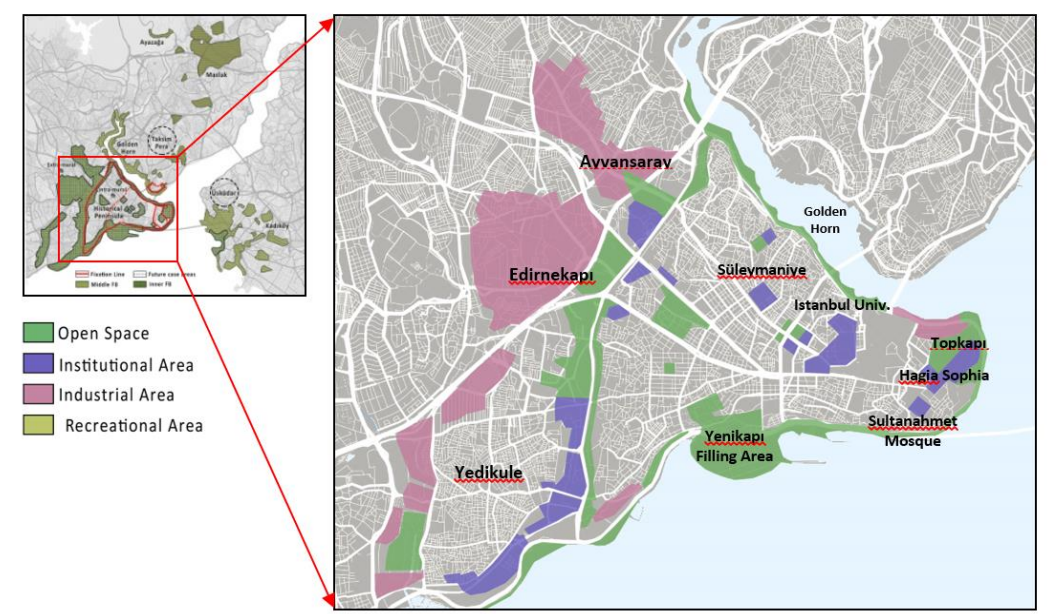

Table 4. The fringe-belt development process of the Golden Horn and the elements of the fringe-belt

\begin{tabular}{|c|c|c|}
\hline \multicolumn{3}{|c|}{ INNER AND MIDDLE FRINGE BELT } \\
\hline \multirow{2}{*}{ Periods } & \multicolumn{2}{|c|}{ Golden Horn } \\
\hline & Change Process & FB Elements \\
\hline $\begin{array}{c}\text { B.C. } 667 \text { - A.C.330 } \\
\text { Byzantion/Chalcedon }\end{array}$ & & \\
\hline $\begin{array}{c}330-476 \\
\text { Roman Empire }\end{array}$ & $\begin{array}{l}\text { The eastern } \\
\text { administrative } \\
\text { center of the } \\
\text { Roman Empire }\end{array}$ & $\begin{array}{l}\text { Harbors, } \\
\text { aqueducts, new } \\
\text { city walls, } \\
\text { temples, forum, } \\
\text { baths, } \\
\text { cemeteries } \\
\text { FB formation }\end{array}$ \\
\hline $\begin{array}{l}476 \text { - } 1453 \\
\text { The Byzantine Empire }\end{array}$ & $\begin{array}{l}\text { Region has a } \\
\text { new wall } \\
\text { system, } \\
\text { settlements } \\
\text { spread North, } \\
\text { developing sea } \\
\text { trace, } \\
\text { population of } \\
\text { the region } \\
\text { decreased }\end{array}$ & $\begin{array}{l}\text { Two main } \\
\text { ports, extra- } \\
\text { mural fringes, } \\
\text { out of wall } \\
\text { settlements, } \\
\text { summer house } \\
\text { areas, } \\
\text { cemeteries } \\
\text { FB formation }\end{array}$ \\
\hline $\begin{array}{l}1453 \text { - 19th c. } \\
\text { Ottoman Empire }\end{array}$ & $\begin{array}{l}\text { Islamic } \\
\text { influence, } \\
\text { increasing } \\
\text { Islamic building, } \\
\text { improving Eyup } \\
\text { and Beyoğlu } \\
\text { settlements, } \\
\text { coast areas as } \\
\text { recreational use }\end{array}$ & $\begin{array}{l}\text { Recreation } \\
\text { areas, coastal } \\
\text { palaces and } \\
\text { mansions, } \\
\text { extra-mural } \\
\text { fringes, } \\
\text { cemeteries } \\
\text { FB } \\
\text { modification } \\
\text { (consolidation, } \\
\text { translation) }\end{array}$ \\
\hline
\end{tabular}

Figure 19. Land use of the current Fringe Belt area in Golden Horn (prepared by author) 


\begin{tabular}{|c|c|c|}
\hline $\begin{array}{l}\text { 19th c. Ottoman Empire } \\
\text { (Westernization) }\end{array}$ & $\begin{array}{l}\text { Developing sea } \\
\text { transport and } \\
\text { transportation } \\
\text { system, } \\
\text { institutional } \\
\text { buildings, } \\
\text { improved } \\
\text { textile industry } \\
\text { and shipyards, }\end{array}$ & $\begin{array}{l}\text { New factories } \\
\text { and shipyard } \\
\text { buildings, } \\
\text { railway } \\
\text { stations, } \\
\text { barracks and } \\
\text { military } \\
\text { facilities, } \\
\text { cemeteries } \\
\text { FB } \\
\text { modification } \\
\text { (consolidation } \\
\text {, alienation) }\end{array}$ \\
\hline $\begin{array}{l}\text { The Republic and the 20th c. } \\
\text { Modern City }\end{array}$ & $\begin{array}{l}\text { New industrial } \\
\text { areas, pollution } \\
\text { in the region, } \\
\text { illegal housing } \\
\text { areas appeared, } \\
\text { Building of } \\
\text { coastal roads }\end{array}$ & $\begin{array}{l}\text { port, illegal } \\
\text { housing areas, } \\
\text { new industrial } \\
\text { building, } \\
\text { cemeteries } \\
\text { FB } \\
\text { modification } \\
\text { (consolidation } \\
\text {, alienation) }\end{array}$ \\
\hline $\begin{array}{c}\text { Metropolitan city (After } \\
\text { 2000) }\end{array}$ & $\begin{array}{l}\text { Decentralizatio } \\
\mathrm{n} \text { of industrial } \\
\text { areas, } \\
\text { Conservation \& } \\
\text { development } \\
\text { projects, } \\
\text { creating cultural } \\
\text { zone, } \\
\text { preservation of } \\
\text { the historical } \\
\text { and cultural } \\
\text { values }\end{array}$ & $\begin{array}{l}\text { Culture, } \\
\text { cemeteries, } \\
\text { tourism and } \\
\text { recreation } \\
\text { areas, } \\
\text { education } \\
\text { areas, low } \\
\text { density } \\
\text { residential } \\
\text { areas } \\
\text { FB } \\
\text { modification } \\
\text { (translation, } \\
\text { consolidation) }\end{array}$ \\
\hline
\end{tabular}

\section{Maslak as a Middle Fringe Belt (MFB):}

The following analysis of the Maslak region is structured by overlapping the land-use maps from 1946 to 2017. Large empty lots and big parcels (plots) for hunting areas, palaces for Ottoman noble (sultan) family, farmlands and military barracks were all existing at Levent-Maslak-Sariyer axis till $18^{\text {th }}$ century. The CBD of the city shifted from the historical peninsula to the Şişli-LeventMaslak axis (Kubat, Hazar, 2018) following the lines of the topography. By the attraction of the two bridges, increased the density and land prices, created alienation process and loss in these fringe uses of $18^{\text {th }}$ century. 

of Istanbul

Within the scope of this study, and in order to comprehend the dynamics of urban transformation, it was essential to focus on the Büyükdere Boulevard which links Şişli, Levent and Maslak regions altogether. Open spaces and low-density (dense) residential areas were redeveloped into military and industrial zones during the Westernization period. However, some low-density residential areas were given over to commercial use and lost their fringe-belt characteristics, as shown in Fig (20).

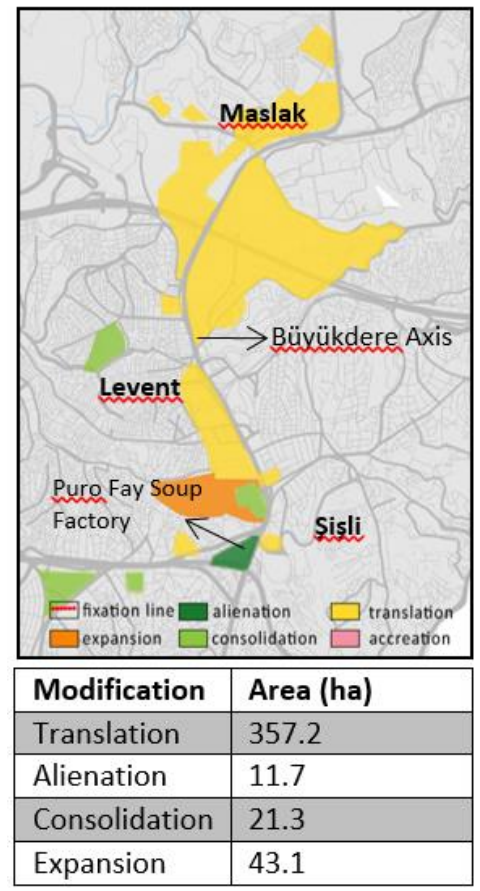

Figure 20. Fringe-belt modification process of Maslak during the Westernization period (1800-1923)

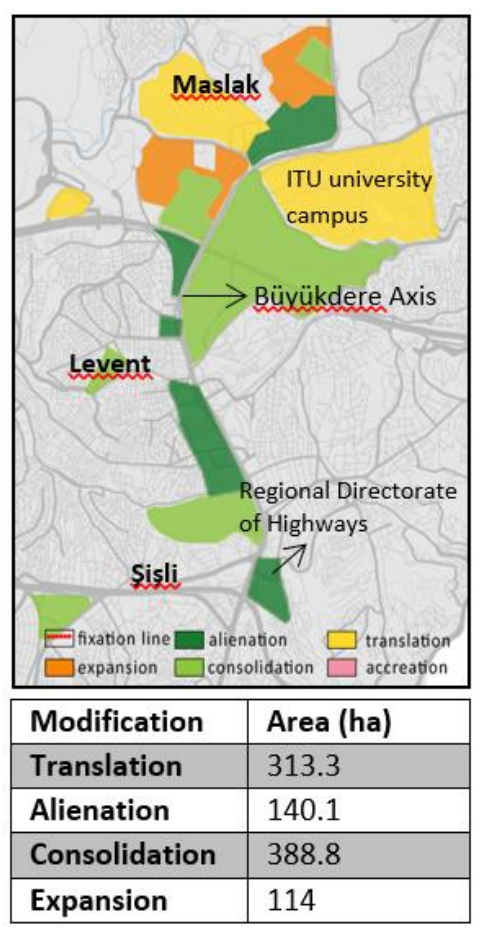

Figure 21. Fringe belt modification process of Maslak during the Republican period (1923-Present) 
During the current Republican period, the military areas have been consolidated and expanded, and the low density residential areas have been transformed into new military and educational areas (The Istanbul Technical University campus). After the construction of the Bosphorus Bridge (1973) and the Fatih Sultan Mehmet Bridge (1988), the CBD moved towards north along the main transportation arteries and the two bridges connecting Europe to Anatolia. Increasing density and land values have caused these areas to lose their fringe-belt characteristics with the result that the Maslak region has become alienated (Fig. 21).

The most remarkable transformation - alienation process (loss to residential or CBD) occurred on the Büyükdere axis of the LeventMaslak area during Republican period (1923 to present). These are; Puro Soap factory (1952) is transformed to TAT Tower Commercial and office uses, Eczacıbaşı Medicine Factory (1942) to Kanyon shopping center \& residential uses (2006), Transformation from Industrial uses and Emergence of two Shopping Malls next to Kanyon: Metrocity and Özdilek Park Shopping malls \& Residences (2003), TC Regional Directorate of Highways Office Building Complex (1970) -former glacis fringe areas/green space of the city- to Zorlu Shopping Center (2013)

From these observations, it can be determined that the land use in the current Middle fringe-belt area in Maslak are cemeteries, industrial areas, educational areas, and sports grounds (Fig. 22). The fringe-belt change process in the Maslak and the elements of the fringe-belt are shown in Table (5).

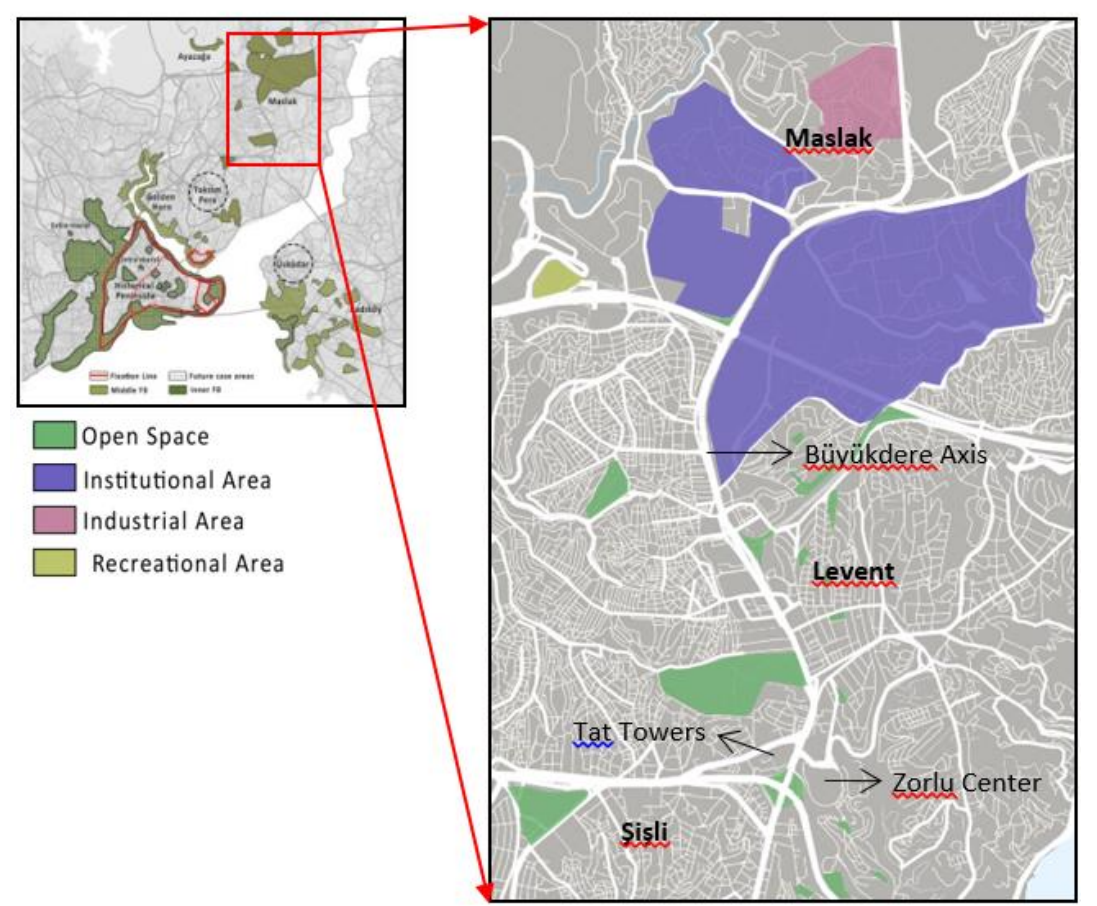

Figure 22. Land use of current Fringe Belt area in Maslak (prepared by author) 

of Istanbul

Table 5. The fringe-belt development process of the Maslak and the elements of the fringe-belt

\begin{tabular}{|c|c|c|}
\hline \multicolumn{3}{|c|}{ MIDDLE FRINGE BELTS } \\
\hline \multirow[t]{2}{*}{ Periods } & \multicolumn{2}{|c|}{ Maslak } \\
\hline & $\begin{array}{l}\text { Change } \\
\text { Process }\end{array}$ & FB Elements \\
\hline $\begin{array}{c}\text { B.C. } 667 \text { - } \\
\text { A.C.330Byzantion/Chalcedon }\end{array}$ & & \\
\hline 330 - 476 Roman Empire & & \\
\hline $\begin{array}{c}476-1453 \text { The Byzantine } \\
\text { Empire }\end{array}$ & & \\
\hline $\begin{array}{c}1453 \text { - 19th c. Ottoman } \\
\text { Empire }\end{array}$ & $\begin{array}{l}\text { First } \\
\text { settlement is } \\
\text { the Levent } \\
\text { Farm in the } \\
\text { city periphery }\end{array}$ & $\begin{array}{l}\text { Farms, military } \\
\text { complexes, } \\
\text { hunting lodges, } \\
\text { huts, waterways, } \\
\text { cemeteries } \\
\text { FB formation }\end{array}$ \\
\hline $\begin{array}{l}\text { 19th c. Ottoman Empire } \\
\text { (Westernization) }\end{array}$ & $\begin{array}{l}\text { New planning } \\
\text { decisions, } \\
\text { pharmaceutical } \\
\text { factories, } \\
\text { increase in } \\
\text { industrial } \\
\text { areas, a new } \\
\text { industry } \\
\text { master plan } \\
\text { designated, the } \\
\text { construction of } \\
\text { a new } \\
\text { boulevard: } \\
\text { Büyükdere axis }\end{array}$ & $\begin{array}{l}\text { low density } \\
\text { residential area, } \\
\text { industrial areas, } \\
\text { sport facilities, } \\
\text { cemeteries, } \\
\text { factories } \\
\text { FB formation }\end{array}$ \\
\hline $\begin{array}{l}\text { The Republic and the 20th } c \text {. } \\
\text { Modern City }\end{array}$ & $\begin{array}{l}\text { Increase in } \\
\text { motor usage, } \\
\text { sub-centers, } \\
\text { obtain world } \\
\text { bank financing, } \\
\text { construction of } \\
\text { the first } \\
\text { Bosphorus } \\
\text { bridge (1973), } \\
\text { transportation } \\
\text { activities } \\
\text { increased the }\end{array}$ & $\begin{array}{l}\text { cemeteries, } \\
\text { military zones, } \\
\text { sport facilities, } \\
\text { low density } \\
\text { residential } \\
\text { areas, } \\
\text { educational } \\
\text { campus, } \\
\text { industrial areas } \\
\text { FB } \\
\text { modification }\end{array}$ \\
\hline
\end{tabular}




\begin{tabular}{|c|c|c|}
\hline & $\begin{array}{l}\text { accessibility in } \\
\text { macro scale }\end{array}$ & $\begin{array}{l}\text { (expansion, } \\
\text { translation) }\end{array}$ \\
\hline $\begin{array}{l}\text { Metropolitan city (After } \\
\text { 2000) }\end{array}$ & $\begin{array}{l}\text { Construction of } \\
\text { FSM } \\
\text { bridge(1988), } \\
\text { The } \\
\text { underground } \\
\text { system put into } \\
\text { service, } \\
\text { industrial } \\
\text { areas } \\
\text { transformed to } \\
\text { CBD usage, } \\
\text { migration, } \\
\text { increase in } \\
\text { population }\end{array}$ & $\begin{array}{l}\text { cemeteries, } \\
\text { military } \\
\text { facilities, sports } \\
\text { areas, low } \\
\text { density } \\
\text { residential } \\
\text { areas, } \\
\text { educational } \\
\text { campus, } \\
\text { industrial areas } \\
\text { FB } \\
\text { modification } \\
\text { (expansion, } \\
\text { translation) }\end{array}$ \\
\hline
\end{tabular}

\section{Ayazağa as a Middle Fringe belt (MFB):}

The following analyses were structured by overlapping land-use maps of 1970 and 2015 of Ayazağa. From this, it can be seen that agricultural areas were transformed into industrial areas during the Westernization period. The first phase of the change can be defined as fringe-belt translation (Fig. 23).

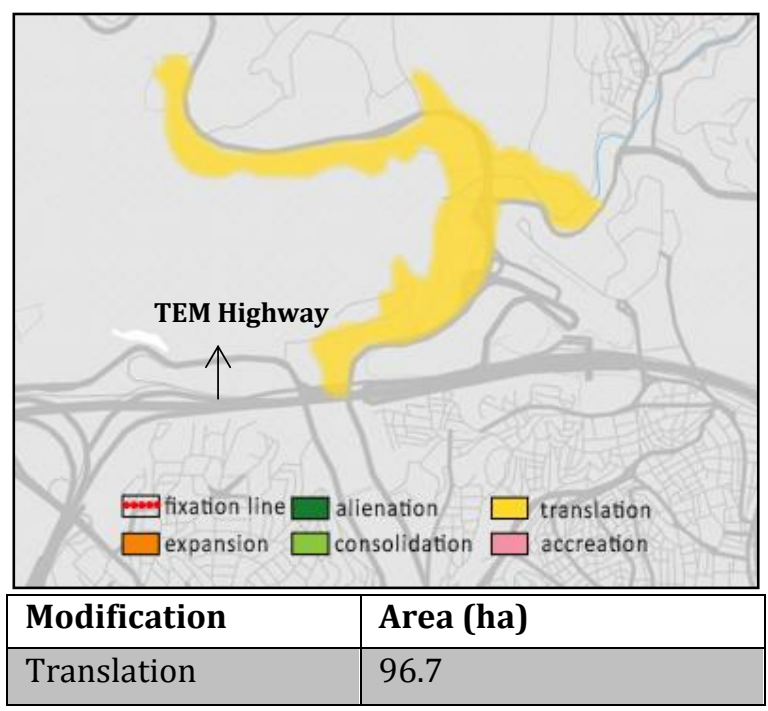

Figure 23. Fringe-belt modification process of Ayazağa during the Westernization period (1800-1923)

The changes within the fringe-belt area of the Ayazağa region during the Republican period are defined as alienation. This is because the industrial areas were transformed into high density residential and commercial areas. In addition, empty lots and open spaces became sports grounds and industrial areas were consolidated (Fig. 24). 
Exploring the Fringe-Belt Phenomenon in a Multi-Nuclear City: The Case of Istanbul

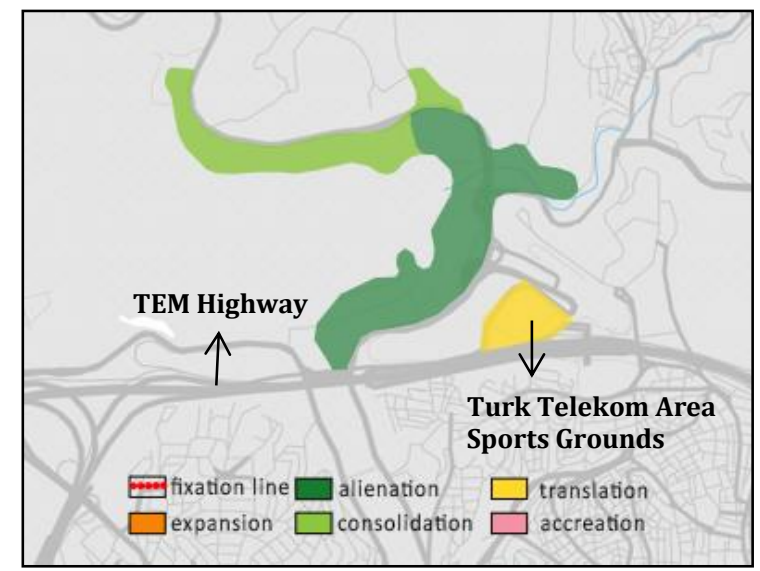

\begin{tabular}{|l|l|}
\hline Modification & Area (ha) \\
\hline Translation & 12.3 \\
\hline Alienation & 65.2 \\
\hline Consolidation & 31.5 \\
\hline
\end{tabular}

These observations show that, the land uses of currently developed Middle Fringe Belt area in Ayazağa are industrial areas and sports grounds as in Fig (25). The fringe-belt change process in the Ayazağa and the elements of the Fringe Belt are shown in Table (6).

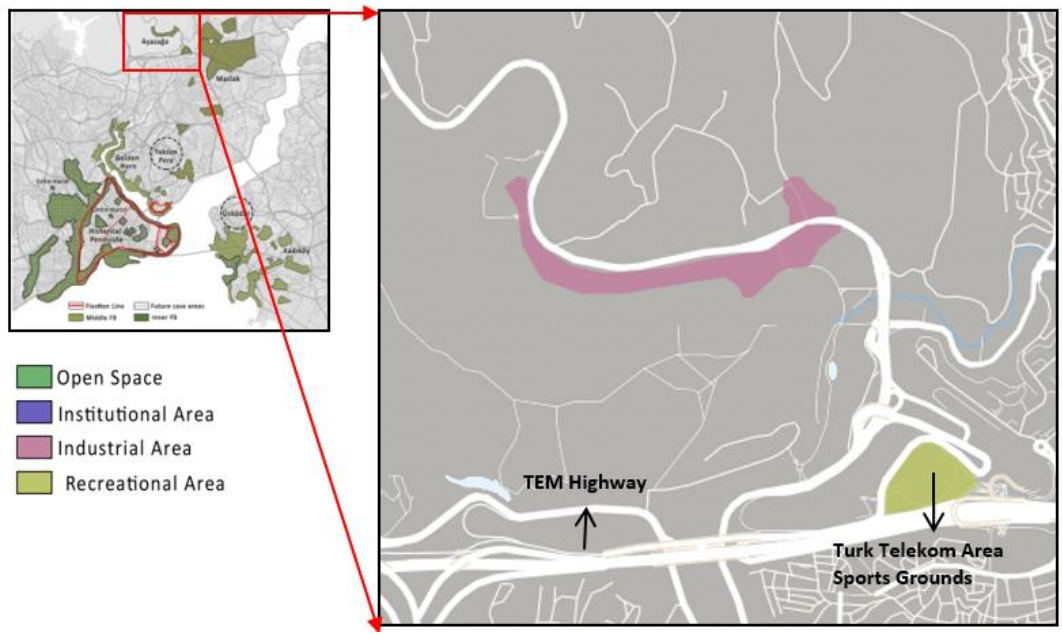

Figure 24. Fringe-belt modification process of Ayazağa during the Republican period (1923- Present)

Figure 25. Land use of current Fringe Belt area in Ayazağa (prepared by author) 
Table 6. The fringe-belt development process of Ayazağa and the elements of the fringe-belt (prepared by author)

\begin{tabular}{|c|c|c|}
\hline \multicolumn{3}{|c|}{ MIDDLE FRINGE BELTS } \\
\hline \multirow[t]{2}{*}{ Periods } & \multicolumn{2}{|c|}{ Ayazağa } \\
\hline & Change Process & FB Elements \\
\hline $\begin{array}{c}\text { B.C. } 667 \text { - } \\
\text { A.C.330Byzantion/Chalcedon }\end{array}$ & & \\
\hline 330 - 476 Roman Empire & & \\
\hline $\begin{array}{c}476 \text { - } 1453 \text { The Byzantine } \\
\text { Empire }\end{array}$ & & \\
\hline $\begin{array}{c}1453 \text { - 19th c. Ottoman } \\
\text { Empire }\end{array}$ & & \\
\hline $\begin{array}{l}\text { 19th c. Ottoman Empire } \\
\text { (Westernization) }\end{array}$ & $\begin{array}{l}\text { Low-density } \\
\text { developments, } \\
\text { agricultural } \\
\text { activities } \\
\text { occurred near } \\
\text { the water } \\
\text { source, } \\
\text { surrounded by } \\
\text { dense forest. }\end{array}$ & $\begin{array}{l}\text { Low density } \\
\text { residential } \\
\text { areas, } \\
\text { agricultural } \\
\text { areas } \\
\text { FB formation }\end{array}$ \\
\hline $\begin{array}{l}\text { The Republic and the 20th c. } \\
\text { Modern City }\end{array}$ & $\begin{array}{l}\text { Industrial areas } \\
\text { developed, } \\
\text { factories, } \\
\text { agricultural } \\
\text { areas } \\
\text { transformed to } \\
\text { industrial areas, } \\
\text { settlements } \\
\text { expanded, the } \\
\text { destruction of } \\
\text { green areas }\end{array}$ & $\begin{array}{l}\text { Industrial } \\
\text { areas, factories, } \\
\text { low density } \\
\text { residential } \\
\text { areas, } \\
\text { FB } \\
\text { modification } \\
\text { (translation) }\end{array}$ \\
\hline $\begin{array}{c}\text { Metropolitan city (After } \\
\text { 2000) }\end{array}$ & $\begin{array}{l}\text { FSM bridge and } \\
\text { TEM highway } \\
\text { built, settlement } \\
\text { density } \\
\text { increased, new } \\
\text { residential and } \\
\text { commercial } \\
\text { areas, relocated } \\
\text { industries, } \\
\text { surrounded by } \\
\text { the construction } \\
\text { of many luxury } \\
\text { brand } \\
\text { residences. }\end{array}$ & $\begin{array}{l}\text { Sports areas, } \\
\text { industrial areas } \\
\text { FB } \\
\text { modification } \\
\text { (alienation) }\end{array}$ \\
\hline
\end{tabular}




\section{Kadıköy as a Middle Fringe Belt (MFB):}

Kadıköy is a major commercial and business center as well as the transportation hub (with its port, train station and underground connection) for the Anatolian side of the city. It was first established in ancient times as the city of "Chalcedon", and was later was used as a summer resort and site for summer residences during the Ottoman period. However, the inner fringe belt observed in Kadıköy does not reflect any similar characteristics to that of the historical peninsula when considering to the whole structure and development cycles of the city. Although the history of the Chalcedon settlement is older than the primary settlement of the historical peninsula, its development remained constant. The fringe-belt formation of Kadıköy can therefore be accepted as the Middle Fringe Belt of metropolitan Istanbul for the purposes of this study.

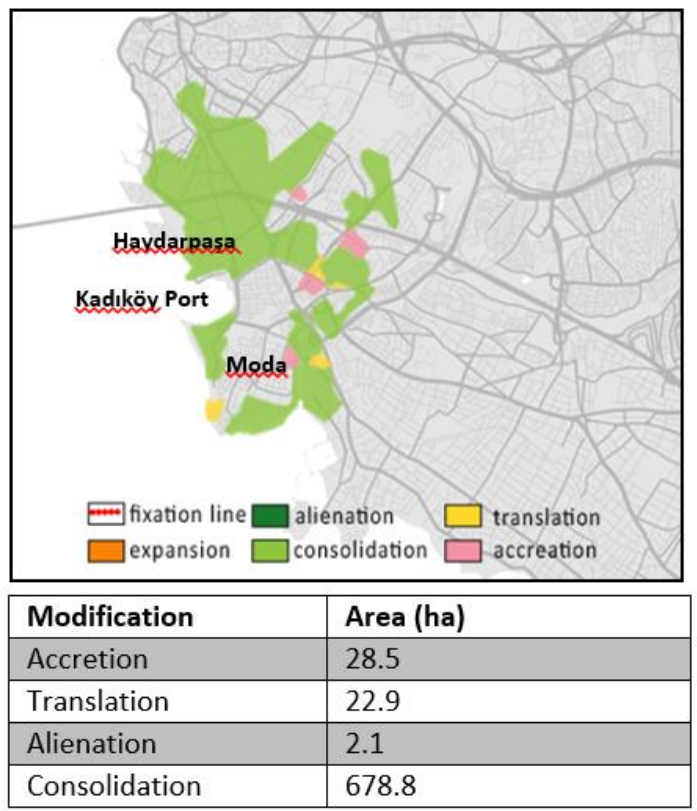

The fringe-belt areas of Kadıköy were in phases of consolidation and accretion during the Ottoman period. Military, educational, industrial, and low density residential areas, as well as gardens were consolidated. However, part of the fringe-belt's open spaces were developed for low density residential housing Fig (26).
Figure 26. Fringe-belt modification process of Kadıköy during the Ottoman period (1453 - 1800) 
Figure 27. Fringe-belt modification process of Kadıköy during the Westernization period (1800-1923)
Figure 28. Fringe-belt modification process of Kadıköy during the Republican period (1923-Present)

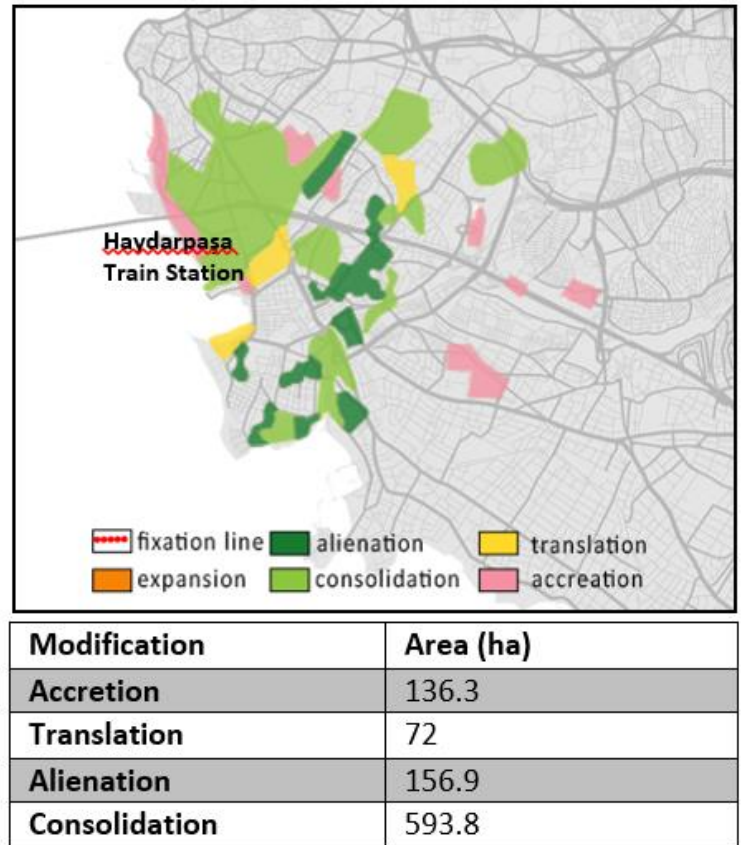

Population increases and initiatives by the municipality caused land use in many fringe-belt areas to be given over for residential and commercial purposes during the Westernization period. At the same time, the construction of the railway and the Haydarpaşa train station in 1908 caused changes to the fringe areas Fig (27).

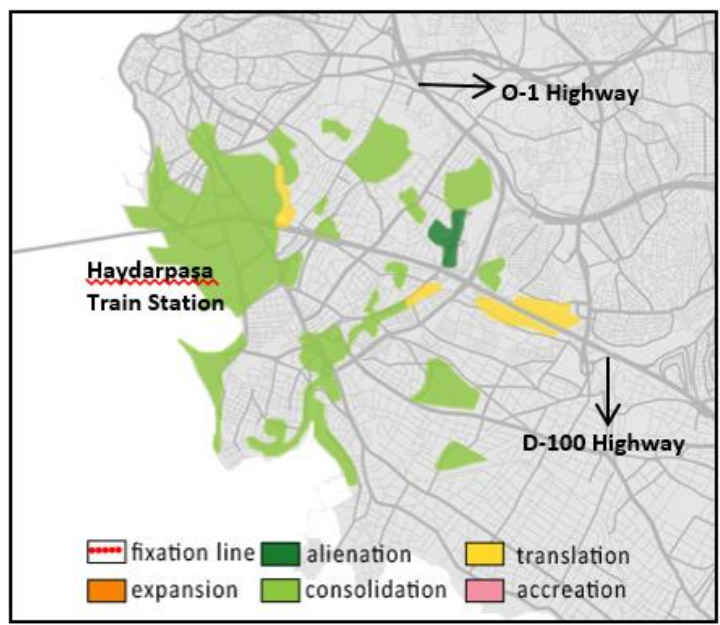

\begin{tabular}{|l|l|}
\hline Modification & Area (ha) \\
\hline Translation & 69.6 \\
\hline Alienation & 27.2 \\
\hline Consolidation & 889.3 \\
\hline
\end{tabular}

Cultural, commercial and recreational uses increased during the Republican period. This is due to the fact that Kadıköy became the center of transportation and transition of the Anatolian side. Although part of the fringe belt area alienated and translated during this period, most areas were consolidated as shown in Fig (28). 


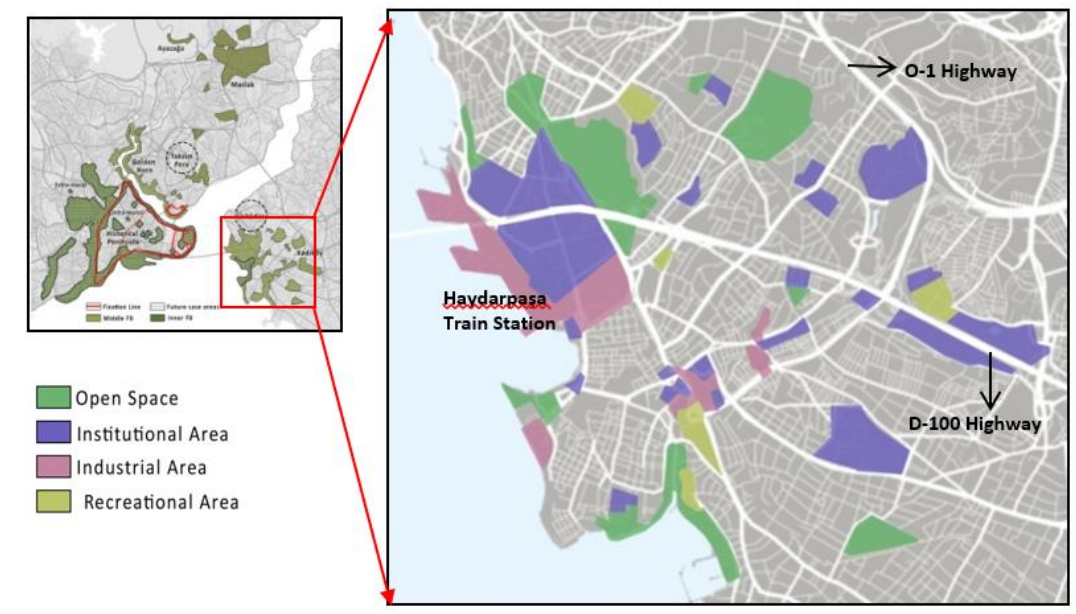

From these observations, it can be determined that the land use in the current inner and Middle Fringe-Belt area in Kadıköy were cemeteries, military zones, educational areas, institutional areas, industrial area, religious area, sports grounds, hospitals and the train station Fig (29). The fringe-belt change process in Kadıköy and the elements of the fringe-belt are shown in Table 7.

Table 7. The fringe-belt development process of Kadıköy and the elements of the fringe-belt (prepared by author)

\begin{tabular}{|c|c|c|}
\hline \multicolumn{3}{|c|}{ INNER AND MIDDLE FRINGE BELTS } \\
\hline \multirow[t]{2}{*}{ Periods } & \multicolumn{2}{|c|}{ Kadıköy } \\
\hline & Change Process & FB Elements \\
\hline $\begin{array}{c}\text { B.C. } 667 \text { - A.C.330 } \\
\text { Byzantion/Chalcedon }\end{array}$ & $\begin{array}{l}\text { Chalcedon as a } \\
\text { Greek city }\end{array}$ & $\begin{array}{l}\text { Institutional areas } \\
\text { (Monumental } \\
\text { structures), } \\
\text { FB formation }\end{array}$ \\
\hline 330 - 476 Roman Empire & $\begin{array}{l}\text { Although the city } \\
\text { did not develop } \\
\text { during this } \\
\text { period, it } \\
\text { remained stable. }\end{array}$ & $\begin{array}{l}\text { Institutional areas } \\
\text { (Monumental } \\
\text { structures), } \\
\text { FB formation }\end{array}$ \\
\hline $\begin{array}{c}476 \text { - } 1453 \text { The Byzantine } \\
\text { Empire }\end{array}$ & $\begin{array}{l}\text { Low density } \\
\text { residential areas } \\
\text { and low } \\
\text { population }\end{array}$ & $\begin{array}{l}\text { Institutional areas } \\
\text { (Monumental } \\
\text { structures), } \\
\text { gardens and } \\
\text { vineyards } \\
\text { FB formation }\end{array}$ \\
\hline $\begin{array}{c}1453 \text { - 19th c. Ottoman } \\
\text { Empire }\end{array}$ & $\begin{array}{l}\text { Chalcedon was } \\
\text { endeavored with } \\
\text { gardens, Kadıköy } \\
\text { became popular } \\
\text { excursion spot, } \\
\text { Usage of } \\
\text { seashores in the } \\
\text { district for second } \\
\text { residences }\end{array}$ & $\begin{array}{l}\text { Recreational } \\
\text { gardens, summer } \\
\text { house areas, low } \\
\text { density } \\
\text { residential areas } \\
\text { FB modification } \\
\text { (translation, } \\
\text { alienation) }\end{array}$ \\
\hline
\end{tabular}

Figure 29. Land use of current Fringe Belt area in Kadıköy (prepared by author) 


\begin{tabular}{|c|c|c|}
\hline $\begin{array}{l}\text { 19th c. Ottoman Empire } \\
\text { (Westernization) }\end{array}$ & $\begin{array}{l}\text { First attempts of } \\
\text { municipal } \\
\text { evolution in } \\
\text { Kadıöy in the } \\
\text { sense of } \\
\text { modernity, } \\
\text { population } \\
\text { increased, } \\
\text { establishment of } \\
\text { the railway } \\
\text { station, } \\
\text { construction of a } \\
\text { hospital, military } \\
\text { facilities and } \\
\text { barracks }\end{array}$ & $\begin{array}{l}\text { Railway station, } \\
\text { military } \\
\text { facilities, } \\
\text { cemeteries, } \\
\text { education, } \\
\text { recreational } \\
\text { area, low } \\
\text { density } \\
\text { residential } \\
\text { areas, hospital, } \\
\text { barracks } \\
\text { FB } \\
\text { modification } \\
\text { (consolidation, } \\
\text { alienation) }\end{array}$ \\
\hline $\begin{array}{l}\text { The Republic and the 20th c. } \\
\text { Modern City }\end{array}$ & $\begin{array}{l}\text { a center for } \\
\text { mosques, } \\
\text { churches and } \\
\text { various official } \\
\text { buildings, } \\
\text { commercial } \\
\text { activity and } \\
\text { residential areas } \\
\text { intensified, } \\
\text { educational areas } \\
\text { increased, } \\
\text { apartmentization }\end{array}$ & $\begin{array}{l}\text { Cemeteries, } \\
\text { military } \\
\text { facilities, } \\
\text { educational } \\
\text { areas, hospital, } \\
\text { low density } \\
\text { residential } \\
\text { areas, sport } \\
\text { facilities, parks } \\
\text { and gardens, } \\
\text { religious } \\
\text { facilities } \\
\text { FB } \\
\text { modification } \\
\text { (consolidation, } \\
\text { alienation) }\end{array}$ \\
\hline $\begin{array}{c}\text { Metropolitan city (After } \\
\text { 2000) }\end{array}$ & $\begin{array}{l}\text { The transit center } \\
\text { of the Anatolian } \\
\text { side, become a } \\
\text { center of social, } \\
\text { cultural and } \\
\text { sportive life, } \\
\text { high-density } \\
\text { settlement } \\
\text { texture }\end{array}$ & $\begin{array}{l}\text { Cemeteries, } \\
\text { military } \\
\text { facilities, } \\
\text { educational } \\
\text { areas, } \\
\text { institutional } \\
\text { areas, industrial } \\
\text { areas, religious } \\
\text { area, sport } \\
\text { areas, hospitals, } \\
\text { train station } \\
\text { FB } \\
\text { modification } \\
\text { (consolidation, } \\
\text { translation) }\end{array}$ \\
\hline
\end{tabular}

\section{CONCLUSION \& DISCUSSION}

Although the suitability of fringe-belt studies to planning practice has previously been discussed, their importance in implementation projects has not yet been understood sufficiently. Nevertheless, in recent years these areas have attracted 
considerable interest in the field of urban morphology. "Though not necessarily immediately apparent on the ground, when mapped and studied developmentally, it is evident that urban fringe belts constitute a major element in the internal structure of cities. They are most apparent where the fixation line has had a powerful constraining influence. Once established they have in many cases had a marked effect on subsequent developments; so that they provide a particularly valuable means of structuring historico-geographical accounts of developing form of cities". (Whitehand, 2007)

Like all urban areas, fringe-belts come by their identities as a result of many interactions and changes. However, very few of these interactions reflect the real characteristics of fringe-belts. From an objective point of view, while fringe-belts can give clues about the growth direction of the physical development of an urban area, they should also be evaluated in a deeper sense and on their own terms. This is because they can provide a valuable frame of reference when attempting to explain the phases of development of the periphery, and also when evaluating the physical evidence left by previous historical periods. Both of these reflect the necessity to focus on studies which examine the historical and geographical structures of cities and which are intended to raise awareness and increase understanding.

When projects are carried out in urban environments and the associated literature is examined, it can be seen that fringe-belt studies have been developed with an emphasis on small-scale cities that still contain their original regions or structures, or on those which have special meaning (Pereira \& Meneguetti, 2011). However, despite the analysis of fringe-belts in smaller, slowgrowth rate cities, it is also a fact that more holistic and comprehensive studies are needed for a multi-center metropolis such as Istanbul.

The inner fringe-belts of Istanbul are in a state of almost continuous change and metamorphosis that is a result of both their economic and historical pasts and the social changes they are currently undergoing. The inner fringe-belts of Istanbul developed an internal history as they were enveloped by the city in an ongoing process that started during the Byzantine Empire. These former inner fringe-belts remain as urban fossils as the built up area spread outward beyond them. During its formative stage, the city progressed from this early fixation phase and expanded until it became strongly tied to its Theodosia walls, leaving the Constantine wall behind as a fossil fringe-belt in the inner part of the Historical Peninsula. Later, an extension phase 
started towards the north; to Istiklal Street and Pera after the construction of the Galata Bridge; and to Taksim, Şişli and Maslak; following the topography and making connections to transportation arteries that give access to the three Bosphorus bridges.

These findings also indicate that during the development stage of Istanbul, the CBD could not be enlarged within the dense structure of the old core. In response to this restriction, it found a corridor by which to supply its needs, and eventually became a new CBD in a different location. Over time, these once peripheral but now embedded fringe-belts adjust to the ever changing dynamic of urban land-use and CBD development. The reduction in the extent of the inner fringe-belt, resulting from the implementation of large development projects in the past decade, has posed a substantial threat to the historical identity of the city.

In addition to the inner fringe-belt's development around the historical walls, Istanbul has a multi-centered and linearly developing characteristic, and the analyses in this study also cover middle fringe-belt regions such as Kadıköy on the Anatolian side and the Golden Horn, Maslak and Sarlyer sub-centers on the European side of the city. Furthermore, it is believed that the fringe-belt analyses of districts/neighborhoods that have peculiar characteristics should be considered separately. In particular, this study of fringe-belts illustrates how Istanbul is very different from its counterparts in Europe and cannot be analyzed in the same manner.

As a result of rapid urbanization and migration, fringe-belt areas within a city may be exposed to "FB Alienation" unless they are protected by strategic plans, conservation zoning plans, and landscape and urban design projects. In the Istanbul case, it is important to preserve the historical and urban identity of the city walls and their surroundings for future generations. As with all ancient structures, the land walls require maintenance and restoration. In addition, for an area with such aesthetic and urban qualities, any green areas should be well designed, pedestrian access should be increased, agriculture should be protected, and landmark viewing corridors should be constructed. It is important to consider fringe-belt areas in terms of their public interest, their common usage potential, and their positive effects on urban ecological sustainability.

This study is an attempt to codify the results from 10 years of academic research and analyses using fringe-belt concepts specifically adapted for the city of Istanbul (Kubat, Gümru, 
Kürkçüoğlu, Sungur, 2013), (Kubat, Gümru, 2014), (Hazar, Kubat, 2015, 2016), (Kubat, Hazar, 2018), (Karaulan, Kubat 2018), (Kubat, 2018). However, it is important to mark and differentiate the fringe-belt concept when it is applied to a multi-nuclear city such as Istanbul from other studies conducted in other countries. The most distinctive feature that arises from the study of this city would be the linear development axis of the CBD that started on the Historical Peninsula and which progressed according to the changing dynamics of the city.

It should be noted that a study of this kind, namely one that attempts to deal with a vast urban structure like Istanbul, could be considered only a beginning as each neighborhood unit and urban project needs to be surveyed separately and requires detailed analysis for it to provide precise data.

\section{ACKNOWLEDGEMENT}

The author would like to thank the students of "Urban Morphology Course" which is supervised by Ayșe Sema Kubat and is held in Urban Design Masters Programme, Institute of Science and Technology of İTÜ, for the collection of data during the field work; Akbaş C., Çelebi E., Kara D., Kuşçu Ç., İnce İ., Or E., Uyar S., and especially Ortaç Ü. Gülsüm, for her work on preparing illustrations for this article.

\section{REFERENCES}

Barke, M. (1982). Beyond the urban growth map: suggestions for more analytical work in urban morphology. Teaching Geography, 7, 111-15.

Barke, M. (1990). Morphogenesis, fringe belts and urban size: an exploratory essay, in Slater. T. R. (ed.) The built form of Western cities, Leicester University Press, 279-97.

Conzen, M.R.G. (1960). Alnwick, Northumberland: a study in town-plan analysis. The Institute Of British Geographers, 27.

Conzen, M.R. G. (1962). The plan analysis of an English city centre, in Norborg, K. (ed.) Proceedings of the International Geographical Union Symposium in Urban Geography, Lund 1960 (Gleerup, Lund).

Conzen, M.P. (2009). How cities internalize their former urban fringes: a cross cultural comparison. Urban Morphology, $13,29-54$.

Ducom, E. (2005). Fringe belts in French cities: a comparative study of Rennes, Nantes and Tours, in Barke, M. (ed.) Approaches in urban morphology (Division of Geography, University of Northumbria, Newcastle upon Tyne), 34-43. 
Gu, K. (2010). Exploring the fringe belt concept in Auckland: an urban morphological idea and planning practice. New Zealand Geographer, 66, 44-60.

Hazar, D., Kubat, A.S. (2012). Fringe belts in the process of urban planning and design: comparative analyses of Istanbul and Barcelona, Journal of $A / Z$, Istanbul Technical University, 12/1, 53-65

Hazar, D. \& Kubat, A.S. (2015). The fringe belt development process of Istanbul. In Ding W. (ed) Conference proceedings of the 23rd International Seminar on Urban Form (ISUF) 2015, 423-436, Nanjing, China.

Istanbul Metropolitan Municipality (IBB) (2005), Tarihi Yarımada koruma amaçlı nazım imar planı raporu, Department of Reconstruction and Urbanism, Directorate of City Planning.

Istanbul Metropolitan Municipality (IBB) (2009), 1/100.000 ölçekli Istanbul çevre düzeni planı raporu, Department of Reconstruction and Urbanism, Directorate of City Planning.

Karaulan, D. \& Kubat, A.S. (2018). Analyzing Fringe belt phenomenon in the historico-geographical structure of Milan, Italy. ICONARP-International Journal of Architecture \& Planning, 6, Issue 2, 304-332.

Kuban, D. (1996). İstanbul Bir Kent Tarihi, Bizantion, Konstantinopolis, İstanbul. Türkiye Ekonomik ve Toplumsal Tarih Vakfi, İstanbul.

Kubat, A. S, (1999) "Morphological History of Istanbul", Urban Morphology, 3 (1), 28-41.

Kubat, A.S. \& Gümru, B. \& Kürkçüoğlu, E. \& Sungur, C. (2013). Landwalls of Istanbul: morphological approach. Presented in the Summer School: Theodosian Land Walls and Urban Agriculture, Kadir Has University. (unpublished)

Kubat, A.S. \& Hazar, D. (2018). İstanbul'un Çeper Kuşak Gelişim Süreci. in Kubat et al (eds) Proceeding Local ISUF Congress in Urban Morphology (II TNUM), Istanbul Technical University, 693-711.

Kubat A.S. (2018). Exploring the fringe belt phenomenon in the case of Istanbul. CYNUM 2018, Cyprus Network of Urban Morphology, Plenary section (invited speech, unpublished).

Louis, H. (1936). "Die geographische Gliederung von GrossBerlin", in Louis, H. and Panzer, W. (eds) Länderkundliche Forschung: Festschrift zur Vollendung des sechzigsten Lebensjahres Norbert Krebs 146-71, Engelhorn, Stuttgart.

Pereira, J.A. \& Meneguetti K.S. (2011). Urban fringe belts in planned new towns: the case of Maringa, Brazil. In 
published paper presented to the $18^{\text {th }}$ ISUF Congress, Montreal, Canada.

Murphy, R.E. (1966). The American city, and Urban Geography, Mac Grew Hill Company, 292.

Ünlü T. (2013) Thinking about fringe belts: a Mediterranean perspective. Urban Morphology, 17(1):5-20.

Ünlü T., Baş Y. (2016) Multi-nuclear growth patterns in a rapidly changing Turkish city: a fringe belt perspective, Urban Morphology 20(2):107-121.

Ünlü T., Baş Y. (2019) The Urban growth and development periods of Turkish cities: a fringe belt perspective, in eds: Ö.B. Özdemir et al, Urban and Regional Planning in Turkey, The Urban Book series, Springer.

Whitehand, J.W.R. (1967). Fringe belts: a neglected aspect of urban geography. Transactions of the Institute of British Geographers, 41, 223-33.

Whitehand, J.W.R. (1972). Building cycles and the spatial pattern of urban growth. Transactions of the Institute of British Geographers, 56, 39-55.

Whitehand, J.W.R. (1987). The changing face of cities: a study of development cycles and urban form. Institute of British Geographers Special Publication, 21 (Blackwell, Oxford).

Whitehand, J.W.R. (1988-2007). Urban fringe belts: development of an idea. Planning Perspectives, 3, 47-58.

Whitehand, J.W.R. \& Morton, N.J. (2003). Fringe belts and the recycling of urban land: an academic concept and planning practice, Environment and Planning B: Planning and Design, 30, 819-39.

Whitehand, J.W.R. \& Morton, N.J. (2004). Urban morphology and planning: the case of fringe belts. Cities, 21, 275-89.

Whitehand, J.W.R. \& Morton, N.J. (2006). The fringe belt phenomenon and socioeconomic change, Urban Studies, 43, 2047-66.

1260-1764-1838-1860-1909-1970 City Maps, Courtesy of The Harvard Map Collection, Harvard College Library

15 ${ }^{\text {th }}$ City Map, German Kartenwerkstatt Map: (https://tr.wikipedia.org/wiki/Dosya:Constantinople_ma p_German.png)

1880-1882 Stolpe Map: Stolpe, C. Plan de Constantinople, avec ses faubourgs, le port et une partie du Bosphore. (https://gallica.bnf.fr/)

1906 Goad Maps: Goad, C.E. Plan d'assurance de Constantinople (https://archnet.org/collections/1569/details)

1922 Gedik Pasha Map: Na, S. H. (1922). Map of Constantinople. Harvard Map Collection, Harvard College Library.

1923-1944 Pervititch Maps: Istanbul in the insurance maps of Jacques Pervititch, İstanbul, 2000 
1913-1914 German Blues Map: German Blues, 1: 1913-1914 Before World War I. Maps of İstanbul / Source: Istanbul Metropolitan Municipality Directorate of Libraries and Museums.

1978 Land Utilization Maps of Golden Horn: G.Tezcan, S. Durgunoğlu, T. Ersen G. Çubuk, M. Tuğcu, N. Anadol, K. Karabey, H.(1978). Haliç ve Çevresi Düzenleme Çalışması, Mimarlık 78/4, 28-41.

2013 Land Utilization Map of Golden Horn: Istanbul Metropolitan Municipality

1946-1966-1970-1982-2006-2011-2013-2014-2015-2017

Aerial Maps: (https://sehirharitasi.ibb.gov.tr )

\section{Resume}

Dr. Ayșe Sema Kubat has degrees of B. Arch and M. Arch and PhD in Urban Design \& Urban Planning from Istanbul Technical University (ITU). She is currently working as a Professor at the Faculty of Architecture, Department of City and Regional Planning of ITU. She has been serving on the Steering and Refereeing Committees of the Space Syntax Symposiums since 2003, and was the chair of the 6th International Space Syntax Istanbul Symposium in June, 2007. Her assistance and cooperation to the research project entitled 21st Centre of Excellence for Sustainable Urban Regeneration (cSUR) (2003-2008) is appreciated as "Honorary Fellow of Global Center of Excellence" at Tokyo University. Dr. Kubat is the chair of the Turkish Network of Urban Morphology and the chair of the 2nd Local Conference of the Network at 2018 at ITU, İstanbul. 